\title{
Exploring the Environmental Physiology of the Indo-Pacific Reef Coral Seriatopora hystrix with Differential Proteomics
}

\author{
Anderson B. Mayfield ${ }^{1,2}$, Yi-Jyun Chen2, Chi-Yu Lu ${ }^{3,4}$, Chii-Shiarng Chen ${ }^{2,5,6}$ \\ ${ }^{1}$ Khaled bin Sultan Living Oceans Foundation, USA \\ ${ }^{2}$ Taiwan Coral Research Center, Taiwan \\ ${ }^{3}$ Department of Biochemistry, College of Medicine, Kaohsiung Medical University, Taiwan \\ ${ }^{4}$ Center for Research Resources and Development, Kaohsiung Medical University, Taiwan \\ ${ }^{5}$ Department of Marine Biotechnology and Resources, National Sun Yat-Sen University, Taiwan \\ ${ }^{6}$ Graduate Institute of Marine Biotechnology, National Dong-Hwa University, Taiwan \\ Email: *andersonblairmayfield@gmail.com
}

How to cite this paper: Mayfield, A.B., Chen, Y.-J., Lu, C.-Y. and Chen, C.-S. (2018) Exploring the Environmental Physiology of the Indo-Pacific Reef Coral Seriatopora hystrix with Differential Proteomics. Open Journal of Marine Science, 8, 223-252. https://doi.org/10.4236/ojms.2018.82012

Received: January 25, 2018

Accepted: March 12, 2018

Published: March 15, 2018

Copyright $\odot 2018$ by authors and Scientific Research Publishing Inc. This work is licensed under the Creative Commons Attribution International License (CC BY 4.0).

http://creativecommons.org/licenses/by/4.0/

\begin{abstract}
Although reef-building corals are threatened by a number of anthropogenic impacts, certain scleractinian-dinoflagellate (genus Symbiodinium) endosymbioses have proven markedly resilient to environmental change. For instance, corals from upwelling habitats of Southern Taiwan withstand both short- and long-term increases in temperature, potentially due to their routine exposure to highly variable temperature regimes in situ. To gain a greater understanding of the proteomic basis for such acclimatization to unstable environmental conditions, specimens of the Indo-Pacific reef-building coral Seriatopora hystrix Dana 1846 were sampled during a period of stable temperature conditions from 1) a site characterized by frequent upwelling events in Southern Taiwan and 2) a nearby, non-upwelling control site in the Taiwan Strait. Two-dimensional gel electrophoresis followed by sequencing of differentially concentrated proteins with mass spectrometry unveiled significantly more proteins involved in the cellular stress response in coral hosts of the upwelling site. Although such stress protein signatures could be indicative of sub-lethal levels of cellular stress, especially given the relatively higher sediment loads characteristic of the upwelling site, these proteins may, in contrast, have been constitutively maintained at high levels in preparation for large fluctuations in temperature and other abiotic parameters (e.g., nutrient levels) brought upon by upwelling events.
\end{abstract}

\section{Keywords}

Acclimation, Coral Reefs, Dinoflagellate, Environmental Physiology, Marine 
Biology, Marine Invertebrates, Molecular Biology, Proteomics, Taiwan

\section{Introduction}

As Earth's oceans continue to warm and acidify [1], scientists are racing to understand the physiological implications of such climate change impacts on marine organisms [2]; there has been a particular focus on taxa known to be environmentally-sensitive, such as reef-building corals [3]. Although it is true that many scleractinian-dinoflagellate (genus Symbiodinium) endosymbioses readily disintegrate (i.e., "bleach") upon prolonged exposure to unfavorable environmental conditions [4], certain species/populations have proven to be markedly plastic and readily acclimatize/acclimate to an array of different environmental conditions in situ [5] [6], as well as in the laboratory [7] [8] [9] [10].

Southern Taiwan has served as an exemplary natural laboratory for understanding how environmental heterogeneity influences coral biology, as there are well-developed coral reefs experiencing very different oceanographic conditions in near vicinity of each other [11]. For instance, corals of Houwan $(\mathrm{HWN})$, a reef within the Taiwan Strait (Figure 1), experience a relatively stable environment with respect to seawater temperature [12], which rarely
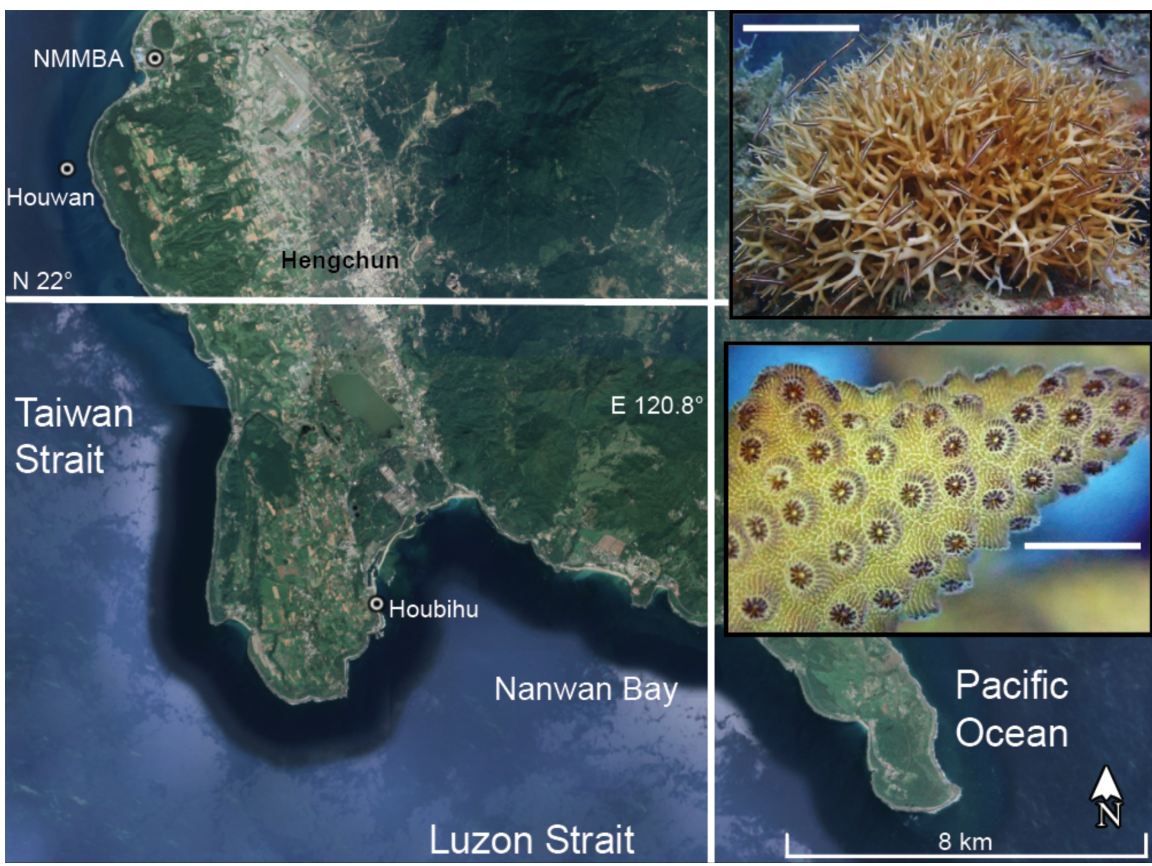

Figure 1. Map of Southern Taiwan featuring the two study sites: Houbihu (upwelling site within Nanwan Bay) and Houwan (non-upwelling, Taiwan Strait control site). Please see Table 1 for a summary of the oceanographic differences between these two sites. Both full-scale (upper inset) and "macro" (lower inset) images of the model coral for this study, Seriatopora hystrix (which is abundant at both sites), have been presented, and white scale bars represent $\sim 10 \mathrm{~cm}$ and $\sim 5 \mathrm{~mm}$, respectively. NMMBA $=$ National Museum of Marine Biology and Aquarium. 
fluctuates more than a $1-2^{\circ} \mathrm{C}$ within a single day. In contrast, the thermal environment of nearby $(\sim 15 \mathrm{~km})$ Houbihu $(\mathrm{HBH})$, which is just around the Maobitou Cape within Nanwan Bay (Taiwan's southernmost embayment; Figure 1), differs dramatically [13]; Nanwan Bay experiences spring tide-induced upwelling events in the boreal summer, during which temperature can change by up to $9^{\circ} \mathrm{C}$ in just a few hours.

To gain greater insight into the molecular biology underlying the ability of corals to thrive in these upwelling environments, biopsies of the common, Indo-Pacific scleractinian Seriatopora hystrix Dana 1846 were taken from the same colonies from which laboratory-based experiments were previously conducted [12] [14] [15] [16] [17] immediately upon removal of the colonies from the ocean at each of the two aforementioned study sites in Southern Taiwan, HBH (the upwelling site) and HWN (the non-upwelling site), during a stable-temperature period (i.e., between upwelling events in the case of $\mathrm{HBH}$ ). It was hypothesized that a two-dimensional (2D) gel electrophoresis approach followed by sequencing of proteins uniquely synthesized by corals of one site and not the other (i.e., uniquely synthesized proteins [USPs]) with mass spectrometry (MS) could aid in elucidating the proteomic basis of survival in a highly variable-temperature environment. Indeed, proteomics-based approaches have aided in our understanding of both the fundamental cell biology of anthozoan-dinoflagellate endosymbioses (e.g., [18] [19] [20]), as well as their responses to high temperatures [21], and it was hypothesized that a number of proteins would be differentially concentrated (i.e., differentially concentrated proteins [DCPs]) between corals of the two study sites; such USPs/DCPs might be linked to cellular processes involved in combatting the major abiotic challenges facing the corals of each habitat.

\section{Materials and Methods}

\subsection{Study Sites}

Both the upwelling site $\mathrm{HBH}\left(21^{\circ} 56^{\prime} 18.01^{\prime \prime} \mathrm{N}, 120^{\circ} 44^{\prime} 45.54^{\prime \prime} \mathrm{E}\right)$ and the non-upwelling site HWN $\left(22^{\circ} 01^{\prime} 23.30^{\prime \prime} \mathrm{N}, 120^{\circ} 41^{\prime} 18.29^{\prime \prime} \mathrm{E}\right)$ have been well characterized with respect to their oceanography [13] and coral reef ecology (e.g., [22] [23]). Although the difference in temperature variability between study sites was the sole focus of prior environmental physiology works on seriatoporid corals from HBH and HWN [12], other oceanographic variables were shown by Liu et al. [22] to differ between them, and these additional seawater quality parameters could likewise influence the physiology of the resident corals. We therefore undertook a meta-analysis of seawater quality at each site by pooling our own published data ([12] [14] [15]) with those of Liu et al. [22]. We now briefly review how these data were collected.

\subsection{Oceanographic and Ecological Data Collection}

The temperature regimes of both the upwelling site $\mathrm{HBH}$ and the non-upwelling, 
Taiwan Strait, control site HWN (Figure 1) were characterized in detail in 2010 at $7-8 \mathrm{~m}$ depth (the depth of coral collection [12]); specifically, temperature was measured at hourly intervals with $\mathrm{HOBO}^{\circledR}$ Pendant data loggers (Onset) for one year. Although the mean annual temperature did not differ between the two sites, the variability did (Table 1 ); the mean monthly temperature range was 2-fold higher at $\mathrm{HBH}$ than $\mathrm{HWN}$ due to spring-tide upwelling events that occur during the boreal summer at the former site only [12].

As mentioned above, prior works on seriatoporid corals from $\mathrm{HBH}$ and $\mathrm{HWN}$ have focused mainly on these temperature differences as being responsible for the physiological heterogeneity documented across the sampled coral colonies (e.g., [12] [14] [15] [16] [17]). However, we considered additional seawater quality parameters herein as being potential drivers of physiological variation between corals of the two study sites by incorporating the data from Liu et al. [22], in which stations 2 and 7 - 8 correspond to $\mathrm{HWN}$ and $\mathrm{HBH}$, respectively. Specifically, Liu et al. [22] measured salinity, $\mathrm{pH}$, dissolved oxygen (DO) content $(\%)$, biochemical oxygen demand $\left(\mathrm{BOD}_{5} ; \mathrm{mg} / \mathrm{L}\right)$, suspended solid levels $(\mathrm{mg} / \mathrm{L})$, turbidity (NTU), and concentrations of nitrite $(\mu \mathrm{g} / \mathrm{L})$, nitrate $(\mu \mathrm{g} / \mathrm{L})$, ammonia $(\mu \mathrm{g} / \mathrm{L})$, phosphate $(\mu \mathrm{g} / \mathrm{L})$, silicate $(\mu \mathrm{g} / \mathrm{L})$, and chlorophyll a $(\mathrm{chl}-a ; \mu \mathrm{g} / \mathrm{L})$ at monthly intervals between 2001 and 2008, and their respective averages across this timespan have been included in Table 1 . Photosynthetically active radiation (PAR) was instead measured at the depth of coral collection $(7-8 \mathrm{~m})$ at hourly intervals by Mayfield et al. [12], with the mean hourly daytime PAR calculated across several days in May 2010 (the month of coral collection) presented in Table 1. Finally, coral cover was estimated at each site as in Tkachenco et al. [24], with modifications made by Liu et al. [22], and the mean average live coral cover (ALCC) values of the latter work have been included in Table 1 for both study sites. Data were compared statistically across sites as described below.

\subsection{Coral Sampling and Incorporation of Data from Past Studies}

Sampling of six $S$. hystrix colonies (see insets of Figure 1) was undertaken at each site in May 2010 (a month in which upwelling events were frequent [12]) during a period of stable (i.e., non-upwelling) temperatures $\left(\sim 26^{\circ} \mathrm{C}\right)$ as in Mayfield et al. [14]. Only visibly healthy corals were sampled, and there were no evident signs of stress (e.g., excessive release of mucus, bacterial infection, bleaching, recent tissue loss, etc.) in any of the 12 colonies. Once at the surface, three small ( $~ 50 \mathrm{mg}$ ) biopsies taken from each colony were submerged in $\sim 2 \mathrm{ml}$ of TRIzol $^{\mathrm{TM}}$ (Life Technologies), and the 36 biopsies were later homogenized with a mortar and pestle at the lab as in Mayfield et al. [14]. Additional tissue biopsies were taken immediately upon removal of the colonies from the ocean in order to determined in situ chl-a content and Symbiodinium density (described in detail in Mayfield et al. [14]). The colonies from which these "in situ biopsies" were taken were transported to the laboratory and fragmented into nubbins for use in a laboratory-based reciprocal transplant [12]. Physiological- and molecular-scale 
Table 1. Oceanographic differences between the two study sites and physiological variation between their resident seriatoporid corals. Please note that all coral physiological and molecular response variables were assessed only after four weeks of husbandry except for the following: chlorophyll a (chl-a; in situ and post-husbandry data obtained), maximum quantum yield of photosystem II (Fv/Fm; in situ and post-husbandry data obtained), Symbiodinium (Sym) density (in situ and post-husbandry data obtained), and two-dimensional (2D) gel electrophoresis + mass spectrometry (MS)-derived protein concentrations (in situ [herein] and post-husbandry data [17] obtained); in the case of the former three parameters only, their in situ values are instead included in the table. All values in the "HBH" (Houbihu) and "HWN" (Houwan) columns represent means ( \pm std. dev.) unless noted otherwise. In the "Conclusion" column, " $<$ " and/or ">" denote statistically significant differences between sites $(P<0.05)$. ALCC $=$ average live coral cover. exp. = experiment. GCP = genome copy proportion (a molecular proxy for Sym density). PAR = photosynthetically active radiation. $\mathrm{SE}=$ standard error. For full gene names, please see the respective references.

\begin{tabular}{|c|c|c|c|c|c|c|}
\hline Parameter & $\mathrm{HBH}$ & HWN & Type of test & Conclusion & Effect of husbandry & $\operatorname{Ref}(s)$ \\
\hline \multicolumn{7}{|c|}{ Seawater quality \& $A L C C$ (in situ data) } \\
\hline Temperature $\left({ }^{\circ} \mathrm{C}\right)$-monthly mean & $26.4 \pm 1.8$ & $26.6 \pm 2.0$ & student's $t$-test & $\mathrm{HBH}=\mathrm{HWN}$ & Not applicable (NA) & [12] \\
\hline Temperature $\left({ }^{\circ} \mathrm{C}\right)$-monthly range & $6.3 \pm 2.0$ & $3.2 \pm 0.6$ & student's $t$-test & $\begin{array}{c}\mathrm{HBH}>\mathrm{HWN} \\
\quad(2 \text {-fold })\end{array}$ & NA & {$[12]$} \\
\hline Salinity & $32.7 \pm 0.5(\mathrm{SE})$ & $32.4 \pm 0.23(\mathrm{SE})$ & student's $t$-test & $\mathrm{HBH}=\mathrm{HWN}$ & Not significant (NS) & {$[12][22]$} \\
\hline Light at $7.5 \mathrm{~m}\left(\mathrm{PAR} ; \mu \mathrm{mol} / \mathrm{m}^{2} / \mathrm{s}\right)$ & $94 \pm 9.1$ & $94 \pm 8.6$ & student's $t$-test & $\mathrm{HBH}=\mathrm{HWN}$ & NS & [12] \\
\hline $\mathrm{pH}$ & $8.28 \pm 0.03(\mathrm{SE})$ & $8.29 \pm 0.02(\mathrm{SE})$ & student's $t$-test & $\mathrm{HBH}=\mathrm{HWN}$ & Not determined (ND) & {$[22]$} \\
\hline Dissolved oxygen (\%) & $118 \pm 3.0(\mathrm{SE})$ & $126 \pm 2.9(\mathrm{SE})$ & student's $t$-test & $\mathrm{HBH}=\mathrm{HWN}$ & ND & [22] \\
\hline $\mathrm{BOD}_{5}(\mathrm{mg} / \mathrm{L})$ & $1.1 \pm 0.1(\mathrm{SE})$ & $1.3 \pm 0.1(\mathrm{SE})$ & student's $t$-test & $\mathrm{HBH}=\mathrm{HWN}$ & ND & [22] \\
\hline$[$ Nitrite] $(\mu \mathrm{g} / \mathrm{L})$ & $2.5 \pm 0.5(\mathrm{SE})$ & $7 \pm 4(\mathrm{SE})$ & student's $t$-test & $\mathrm{HBH}=\mathrm{HWN}$ & ND & [22] \\
\hline [Nitrate] $(\mu \mathrm{g} / \mathrm{L})$ & $49 \pm 13$ (SE) & $53 \pm 9(\mathrm{SE})$ & student's $t$-test & $\mathrm{HBH}=\mathrm{HWN}$ & ND & [22] \\
\hline [Ammonia] $(\mu \mathrm{g} / \mathrm{L})$ & $35 \pm 11(\mathrm{SE})$ & $63 \pm 21(\mathrm{SE})$ & student's $t$-test & $\mathrm{HBH}=\mathrm{HWN}$ & ND & {$[22]$} \\
\hline [Phosphate] ( $\mu \mathrm{g} / \mathrm{L})$ & $3.5 \pm 1.5(\mathrm{SE})$ & $9 \pm 3$ (SE) & student's $t$-test & $\mathrm{HBH}=\mathrm{HWN}$ & ND & {$[22]$} \\
\hline [Silicate] $(\mu \mathrm{g} / \mathrm{L})$ & $600 \pm 60(\mathrm{SE})$ & $400 \pm 80$ (SE) & student's $t$-test & $\begin{array}{c}\mathrm{HBH}>\mathrm{HWN} \\
\quad(1.5 \text {-fold })\end{array}$ & ND & [22] \\
\hline [Suspended solids] (mg/L) & $20 \pm 3$ (SE) & $12 \pm 2(\mathrm{SE})$ & student's $t$-test & $\begin{array}{l}\mathrm{HBH}>\mathrm{HWN} \\
\quad(1.6 \text {-fold })\end{array}$ & ND & {$[22]$} \\
\hline Turbidity (NTU) & $7.2 \pm 1.6(\mathrm{SE})$ & $3.3 \pm 0.8$ (SE) & student's $t$-test & $\begin{array}{l}\mathrm{HBH}>\mathrm{HWN} \\
\quad(2 \text {-fold })\end{array}$ & ND & {$[22]$} \\
\hline$[\mathrm{Chl}-\mathrm{a}](\mu \mathrm{g} / \mathrm{L})$ & $0.26 \pm 0.07(\mathrm{SE})$ & $0.25 \pm 0.03(\mathrm{SE})$ & student's $t$-test & $\mathrm{HBH}=\mathrm{HWN}$ & ND & [22] \\
\hline $\operatorname{ALCC}(\%)$ & $43 \pm 25$ & $28 \pm 25$ & student's $t$-test & $\mathrm{HBH}=\mathrm{HWN}$ & ND & {$[22]$} \\
\hline \multicolumn{7}{|c|}{$\begin{array}{l}\text { Coral physiology and biological composition (in situ data for all response variables except growth, } \\
\qquad R N A / D N A \text { ratio, protein/DNA ratio, and the Sym GCP) }\end{array}$} \\
\hline Growth $\left(\mathrm{mg} / \mathrm{cm}^{2} /\right.$ day $)$ & $0.8 \pm 0.2$ & $0.7 \pm 0.2$ & student's $t$-test & $\mathrm{HBH}=\mathrm{HWN}$ & ND (did not assess in situ) & [12] \\
\hline Sym density $\left(\right.$ cells $\left./ \mathrm{cm}^{2}\right)$ & $3.1 \pm 1.0$ & $3.0 \pm 0.3$ & Wilcoxon test ${ }^{\mathrm{a}}$ & $\mathrm{HBH}=\mathrm{HWN}$ & $\begin{array}{c}\text { Yes (increased), } \mathrm{HWN}> \\
\mathrm{HBH} \text { post-exp. }\end{array}$ & {$[14]$} \\
\hline Areal chl- $a\left(\mu \mathrm{g} / \mathrm{cm}^{2}\right)$ & $2.8 \pm 1.2$ & $3.1 \pm 0.8$ & student's $t$-test ${ }^{\mathrm{b}}$ & $\mathrm{HBH}=\mathrm{HWN}$ & $\begin{array}{l}\text { Yes (increased), } \mathrm{HBH}> \\
\text { HWN post-exp. }\end{array}$ & [14] \\
\hline Chl-a/cell (pg/cell) & $0.9 \pm 0.3$ & $1.0 \pm 0.3$ & student's $t$-test & $\mathrm{HBH}=\mathrm{HWN}$ & Yes (increased) & [14] \\
\hline Fv/Fm (dark-adapted) & $0.74 \pm 0.01$ & $0.75 \pm 0.01$ & student's $t$-test & $\mathrm{HBH}=\mathrm{HWN}$ & $\begin{array}{c}\text { Yes (increased), } \mathrm{HBH}> \\
\text { HWN post-exp. }\end{array}$ & [12] [14] \\
\hline RNA/DNA ratio & $0.4 \pm 0.2$ & $0.4 \pm 0.1$ & student's $t$-test ${ }^{\mathrm{b}}$ & $\mathrm{HBH}=\mathrm{HWN}$ & ND & [12] \\
\hline
\end{tabular}


Continued

\begin{tabular}{|c|c|c|c|c|c|c|}
\hline Parameter & $\mathrm{HBH}$ & HWN & Type of test & Conclusion & Effect of husbandry & $\operatorname{Ref}(s)$ \\
\hline Protein/DNA ratio & $13 \pm 4$ & $18 \pm 6$ & student's $t$-test ${ }^{\mathrm{b}}$ & $\mathrm{HWN}>\mathrm{HBH}$ (1.4-fold) & ND & [12] \\
\hline Sym GCP & $16 \pm 7$ & $15 \pm 6$ & student's $t$-test & $\mathrm{HBH}=\mathrm{HWN}$ & ND & {$[12]$} \\
\hline \multicolumn{7}{|c|}{ Sym gene expression (normalized to the exogenous Solaris ${ }^{\circledR} R N A$ spike \& Sym GCP as in } \\
\hline Sym apxl (stress response) & $2.8 \pm 1.4$ & $3.5 \pm 2.5$ & student's $t$-test & $\mathrm{HBH}=\mathrm{HWN}$ & ND & {$[12]$} \\
\hline Sym $h s p 70$ (stress response) & $670 \pm 270$ & $740 \pm 290$ & student's $t$-test ${ }^{\mathrm{b}}$ & $\mathrm{HBH}=\mathrm{HWN}$ & ND & [15] \\
\hline Sym pgpase (photosynthesis) & $12 \pm 5.2$ & $13 \pm 7.4$ & student's $t$-test ${ }^{c}$ & $\mathrm{HBH}=\mathrm{HWN}$ & ND & [12] \\
\hline Sym psI(photosynthesis) & $101 \pm 50$ & $74 \pm 51$ & student's $t$-test ${ }^{\mathrm{b}}$ & $\mathrm{HBH}>\mathrm{HWN}$ (1.5-fold) & ND & {$[12]$} \\
\hline Sym $r b c L$ (photosynthesis) & $30 \pm 21$ & $40 \pm 35$ & student's $t$-test ${ }^{\mathrm{c}}$ & $\mathrm{HBH}=\mathrm{HWN}$ & ND & {$[12]$} \\
\hline Sym nrt2 (metabolism) & $750 \pm 230$ & $1060 \pm 760$ & student's $t$-test ${ }^{\mathrm{b}}$ & $\mathrm{HBH}=\mathrm{HWN}$ & ND & [15] \\
\hline \multicolumn{7}{|c|}{$\begin{array}{l}\text { Host coral gene expression (normalized to the exogenous Solaris }{ }^{\circledR} \text { RNA spike \& host } \\
\text { GCP as in Putnam et al. [56]; in situ gene expression levels were not determined.) }\end{array}$} \\
\hline Host $h s p 70$ (stress response) & $75 \pm 12$ & $71 \pm 11$ & student's $t$-test & $\mathrm{HBH}=\mathrm{HWN}$ & ND & [15] \\
\hline Host $a c t b$ (cytoskeleton) & $110 \pm 31$ & $107 \pm 33$ & student's $t$-test ${ }^{\mathrm{b}}$ & $\mathrm{HBH}=\mathrm{HWN}$ & ND & [15] \\
\hline Host ezrin (cytoskeleton) & $58 \pm 35$ & $80 \pm 27$ & student's $t$-test & $\mathrm{HBH}=\mathrm{HWN}$ & $\mathrm{ND}$ & {$[15]$} \\
\hline Host trpl (cytoskeleton) & $23 \pm 8.2$ & $28 \pm 8.5$ & student's $t$-test & $\mathrm{HBH}=\mathrm{HWN}$ & ND & {$[15]$} \\
\hline Host tuba (cytoskeleton) & $230 \pm 81$ & $220 \pm 51$ & student's $t$-test & $\mathrm{HBH}=\mathrm{HWN}$ & ND & [15] \\
\hline Host cplap2 (osmoregulation) & $1.5 \pm 0.66$ & $2.1 \pm 0.78$ & student's $t$-test & $\mathrm{HBH}=\mathrm{HWN}$ & ND & [15] \\
\hline Host oatp (osmoregulation) & $5.7 \pm 2.6$ & $5.4 \pm 1.6$ & student's $t$-test & $\mathrm{HBH}=\mathrm{HWN}$ & ND & {$[15]$} \\
\hline Host $\operatorname{trcc}$ (osmoregulation) & $210 \pm 81$ & $210 \pm 76$ & student's $t$-test ${ }^{\mathrm{b}}$ & $\mathrm{HBH}=\mathrm{HWN}$ & ND & {$[15]$} \\
\hline \multicolumn{7}{|c|}{ Sym protein expression (western blot-derived; concentration normalized to the Sym GCP) } \\
\hline Sym RBCL (photosynthesis) & $320 \pm 170$ & $200 \pm 94$ & student's $t$-test ${ }^{\mathrm{b}}$ & $\mathrm{HBH}=\mathrm{HWN}$ & $\mathrm{ND}$ & [16] \\
\hline All 23 response variables lis & ed above (sta & lardized) & PERMANOVA & $\mathrm{HBH}=\mathrm{HWN}$ & ND & herein \\
\hline Protein expression $(2 D+M S)$ & $\begin{array}{l}15 \text { proteins } \\
\text { across } 3 \\
\text { sequenced } \\
\text { spots }\end{array}$ & $\begin{array}{l}38 \text { proteins } \\
\text { across } 6 \\
\text { sequenced } \\
\text { spots }\end{array}$ & $\begin{array}{l}\text { See text for } \\
\text { details. }\end{array}$ & See text for details. & ND & $\begin{array}{l}\text { Herein \& } \\
\quad[17]\end{array}$ \\
\hline
\end{tabular}

${ }^{a}$ unequal variance; ${ }^{b} \log$-transformed data; ${ }^{c}$ square root-transformed data.

data from the same coral colonies as those analyzed herein ([12] [14] [15] [16] [17]) have been summarized in Table 1 in a similar manner as for the previously acquired seawater quality data in order to more thoroughly assess environmental differences in the physiology of $S$. hystrix in Southern Taiwan. This meta analysis was also carried out to better understand the effect of experimental husbandry on coral physiology (sensu Mayfield et al. [14]), since Symbiodinium densities and chl-a concentrations, as well as the maximum dark-adapted yield of photosystem II (Fv/Fm), were documented both in situ and after four weeks of aquarium husbandry for corals of both study sites. 


\subsection{Coral Protein Extraction, 2D Gel Electrophoresis, and MS}

Proteins from one of the three technical replicates from each of three randomly chosen colonies from each of the two sites were purified as in Mayfield et al. [16]. These six samples represent those biopsies preserved immediately upon removal from the source colonies from the ocean and were therefore meant to be representative of "in situ protein concentrations." Proteins $(n=6)$ were extracted as in Mayfield et al. [25], precipitated in acetone, washed, dried, dissolved in $\sim 150 \mu \mathrm{L}$ of rehydration buffer (9.5 M urea, $2 \%$ CHAPS, $0.5 \%$ carrier ampholytes, and $65 \mathrm{mM}$ dithiothreitol), and $20 \mu \mathrm{L}$ of solubilized protein were quantified with the 2D Quant kit (Amersham Biosciences). The transcriptomes of all 12 colonies, including the 6 whose proteomes were analyzed herein, were sequenced previously [17], albeit after three weeks of acclimation and one week of experimentation (stable vs. variable temperature regimes [12]).

Proteins $(\sim 130 \mu \mathrm{g})$ were electrophoresed across $2 \mathrm{D}$ as in Mayfield et al. [16]; however, as this book chapter is not freely available except on ABM's personal website (http://coralreefdiagnostics.com/), certain key details, which can also be found in Mayfield et al. [26], been reiterated below. Briefly, upon electrophoresing the protein samples ( $\mathrm{n}=3$ for each of two sites of origin: HBH vs. HWN) across 2D (isoelectric focusing for isoelectric point [pI] determination and SDS-PAGE for molecular weight [in $\mathrm{kDa}$ ] determination) as described in Mayfield et al. [26], gels were fixed and stained with SYPRO ${ }^{\circledR}$ Ruby (Life Technologies). They were then imaged by a Typhoon Trio ${ }^{\mathrm{Tx}}$ scanner (GE Healthcare), and ImageQuant TL software (GE Healthcare) was used to identify USPs, or, when USPs were not uncovered, DCPs, between each pair of $\mathrm{HBH}$ and HWN gels. Two gels were run simultaneously on each of three days: one HWN sample and one HBH sample. DCP/USP pIs and molecular weights were recorded from the $1^{\text {st }}$ and $2^{\text {nd }} \mathrm{HBH}$ vs. HWN gel pairs. When these same protein spots were also differentially concentrated between gels, or uniquely synthesized by corals of one of the two sites, in the third pair of biological replicates, they were removed from the gel in which their concentration was higher (referred to herein as the "representative" gel), digested with trypsin, and prepared for MS as in Mayfield et al. [16] [26].

In general, only protein spots that were uniquely synthesized by coral samples of one site and not the other in all three pairs of gels were removed from the final, representative gel and sequenced, though two protein spots that were instead more concentrated by HBH samples in all three gel pairs (i.e., DCPs, rather than USPs) were removed from the final HBH gel and analyzed by MS. In total three $\mathrm{HBH}>\mathrm{HWN}$ and six $\mathrm{HWN}>\mathrm{HBH}$ spots were in-gel digested with trypsin and purified as in Mayfield et al. [16] [26]. Then, $2 \mu \mathrm{L}$ of purified, trypsin-digested peptides were injected into a nano-liquid chromatography system and detected by an LTQ Orbitrap "Discovery Hybrid Fourier Transform" mass spectrometer (Thermo-Fisher) at a resolution of 30,000 coupled with a nanospray source that was executed in positive ion mode. The nano-UPLC system 
("nanoACQUITY"), desalting (Symmetry C18; $5 \mu \mathrm{m} \times 180 \mu \mathrm{m} \times 20 \mathrm{~mm}$ ), and analytical (BEH C18; $1.7 \mu \mathrm{m} \times 75 \mu \mathrm{m} \times 150 \mathrm{~mm}$ ) columns were all purchased from Waters. The peptide eluate from the column was directed to the nanospray source, and the MS was operated in data-dependent mode.

\subsection{Data Analysis-I: Oceanographic, Ecological, and Target Response Variable Data}

When oceanographic (e.g., temperature), ecological (ALCC), and molecular physiological (i.e., the 23 response variables analyzed previously in the sampled colonies; Table 1) data were normally distributed and of homogeneous variance across the two study sites, their means were compared across sites with student's $t$-tests. Wilcoxon tests were used when log- or square root-transformations did not lead to normally distributed (Shapiro-Wilk test, $P<0.05$ ) or homogeneously variable (Levene's test, $P<0.05)$ datasets between sites. In certain cases, both in situ data (Symbiodinium density, Fv/Fm, and chl-a content) and data following four weeks of experimental husbandry (described in Mayfield et al. [14]) were available. In these cases, repeated-measures ANOVAs were instead used to determine whether husbandry had a differential effect on corals of the two study sites. All univariate statistical analyses were carried out with JMP ${ }^{\circledR}$ (ver. 12.0.1). Finally, a multivariate approach aimed at modeling site differences in coral physiology (sensu Mayfield [27]) was carried out with PRIMER (ver. 6) with all 23 response variables (standardized prior to analysis), testing site of origin as the fixed factor. PERMANOVA is based on similarity (Bray-Curtis) between samples and so does not require that data are normally distributed and of homogenous variance (as does MANOVA, which is sensitive to significant deviations from normality and cannot be used in cases such as this study in which there are more response variables $[n=23]$ than samples $[n=12]$ ).

\subsection{Data Analysis-II: MS}

.MGF data files from the mass spectrometer $(n=6)$ were directly uploaded into the MS-SCAN program featured on the $S$. hystrix-Symbiodinium transcriptome server (http://symbiont.iis.sinica.edu.tw/s_hystrix/static/html/\#mscan), and all default conditions of the MS-GF+ script [28] upon which MS-SCAN is based were used (discussed on the open access website housing the script:

https://omics.pnl.gov/software/ms-gf); this included up to two missed cleavages allowed. However, as 1) Chiva et al. [29] found that sequence datasets featuring such missed cleavages are not inherently biased with respect to quantification, and 2) Mayfield et al. [16] found the $S$. hystrix-Symbiodinium proteome to be lysine- and arginine-rich, we generally included sequences containing over two missed cleavages provided that either 15 amino acids (AA) were sequenced at minimum or, alternatively, two peptides mapped to the same reference protein whose collective length was $\geq 15 \mathrm{AA}$. A decoy database (sensu [30]) was not queried to calculate a false discovery rate since there is no fully sequenced proteome 
for a coral or Symbiodinium. Instead, the aforementioned peptide length criteria were increased above the default minimum of 6 AA of MS-GF+ to ensure that only peptides that could be identified with confidence were considered in the analysis. This undoubtedly reduced the total number of DCPs identified. Additional details of MS-GF+, which, unlike Mascot (Matrix Sciences), is free, can be found in Kim and Pevzner [28].

When peptides could be identified with confidence ( $\geq 15$ AA mapping to a translated contig in the $S$. hystrix-Symbiodinium transcriptome) with MS-SCAN, they were assigned a compartment of origin (host, Symbiodinium, intermediate [either host coral or Symbiodinium], or unknown), as well as a protein identity and functional category (e.g., metabolism) when the top hit contig (mRNA) hypothetically encoding the sequenced peptide aligned significantly $\left(e<10^{-5}\right)$ to a functionally characterized protein in the NCBI nr database. The full mRNA sequence of the top hit contig derived from MS-SCAN analysis of the spectral data, rather than the peptide sequence itself, was used as the query (BLASTx) of the NCBI database; this is because trypsin-digested peptides are generally short (mean length $=22 \pm 9$ [std. dev.] AA herein; see Table S1 located at the end of the manuscript.), and such short sequences may not align significantly to any homolog on a public sequence repository like NCBI. However, when $>30$ contiguous AA were sequenced from a single protein, the peptide sequence itself was additionally BLASTed (BLASTp) against the NCBI database to attempt to corroborate the BLASTx analysis of the respective mRNA.

The compartmental breakdowns of the differentially concentrated proteomes were compared to the S. hystrix: Symbiodinium mRNA ratio of 1.8 [17] with $z$-tests. This approach aimed to determine whether one member of the endosymbiosis contributed relatively more USPs/DCPs than the other for 1) all DCPs, 2) the HWN > HBH DCPs, and 3) the HBH > HWN DCPs. Two-sample proportion tests were used to determine whether 1) certain functional categories differed in proportional abundance between the $\mathrm{HWN}>\mathrm{HBH}$ and $\mathrm{HBH}>$ HWN proteomes and 2) certain functional categories were significantly over-represented relative to the stable vs. variable differentially concentrated proteome of Mayfield et al. [17]. For all such statistical analyses, an alpha level of 0.05 was established a priori.

As the transcriptomes of nubbins generated from the colonies analyzed herein were sequenced previously ( 6 nubbins from each site of origin sequenced after one month of experimental husbandry [17]), the expression data from all mRNAs encoding the 53 DCPs uncovered herein were acquired from the $S$. hystrix-Symbiodinium transcriptome server

(http://symbiont.iis.sinica.edu.tw/s_hystrix/static/html/\#stat), and 2-way ANOVAs were performed to determine the effects of site of origin ( $\mathrm{HWN}$ vs. $\mathrm{HBH}$ ), temperature treatment (stable vs. variable; see Mayfield et al. [12] [17] for details.), and their interaction. When a site of origin difference was statistically significant $(P<0.05)$ and matched that observed at the protein level documented 
herein, congruency between mRNA expression and protein concentration was said to have occurred. For instance, if the 2-way ANOVA revealed that a gene was expressed at 2-fold-higher levels in corals of $\mathrm{HBH}$, and the protein spot was more highly concentrated (or uniquely identified) in the final, representative HBH protein gel, molecular congruency was deemed to have been verified. Two-sample proportion tests were used to determine whether congruency differed significantly across 1) compartments (host coral vs. Symbiodinium), 2) site of origin (HBH vs. HWN), and 3) experiments (this study compared to a variable temperature study performed with these same samples [17]).

\section{Results}

\subsection{Seawater Quality}

Although most seawater quality parameters were similar between HWN and $\mathrm{HBH}$, several differed significantly upon pooling data over an eight-year period (Table 1); notably, silicate concentration, suspended solid levels, and turbidity were all significantly higher at $\mathrm{HBH}(P<0.05)$, which abuts a marina, than HWN, which is adjacent to Taiwan's National Museum of Marine Biology and Aquarium (NMMBA; Figure 1; where all laboratory work was undertaken). As reported previously [12], the mean monthly temperature range at $\mathrm{HBH}$ of $\sim 6^{\circ} \mathrm{C}$ was approximately double that of $\mathrm{HWN}\left(\sim 3^{\circ} \mathrm{C}\right.$; Table 1$)$ in the year of coral sampling (2010).

\subsection{Overview of Coral Physiology Results}

In addition to the $2 \mathrm{D}+\mathrm{MS}$ results generated herein, we aimed to first provide a brief overview of previous findings obtained from these same coral colonies. We first summarize the influence of a one-month experimental husbandry on coral nubbins from the two study sites that were fragmented from the same source colonies from which biopsies were taken herein for 2D + MS analysis ("Effect of experimental husbandry"); these findings are described in detail in Mayfield et al. [14]. Then, we briefly summarize the findings of two prior works (Mayfield et al. [12] [15]) in which 23 molecular-physiological response variables were measured in coral nubbins generated from the same source colonies as those analyzed herein, albeit exposed to stable or variable temperatures for one week (following three weeks of acclimation; "Coral molecular physiology differences between upwelling $(\mathrm{HBH})$ and non-upwelling ( $\mathrm{HWN})$ study sites"). Upon presenting the $2 \mathrm{D}+\mathrm{MS}$ data produced herein (" $2 \mathrm{D}+\mathrm{MS}$ "), we then compare the results obtained to those of another study with these same samples [17] that instead sought to model temperature-related, rather than site of origin-associated, differences in protein concentrations ("Comparison with a stable vs. variable temperature regime study carried out with $S$. hystrix"). It should be mentioned that all 12 colonies were of the identical genotype (determined by analysis of microsatellites [15]) and hosted Symbiodinium of clade C exclusively [15]. 


\subsection{Effect of Experimental Husbandry}

As discussed in more detail in Mayfield et al. [14], some coral response variables did change in response to four weeks of experimental husbandry (three weeks of $26^{\circ} \mathrm{C}$-acclimation and one week of experimentation [stable vs. variable temperature regime]; see Mayfield et al. [12] for details.), and husbandry differentially affected corals of the two sites; Symbiodinium density increased more after four weeks of husbandry for corals of HWN than for those of HBH, whereas chl-a concentration and $\mathrm{Fv} / \mathrm{Fm}$ increased more over this period for corals of $\mathrm{HBH}$ (Table 1).

\subsection{Coral Molecular Physiology Differences between Upwelling (HBH) and Non-Upwelling (HWN) Study Sites}

Of the 23 response variables measured in corals of the two study sites (Table 1; see Mayfield et al. [12] [15] for details.), only the protein/DNA ratio and Symbiodinium photosystem I (subunit III; $p s I$ ) mRNA expression differed significantly between corals of the upwelling and non-upwelling sites (Table 1). Regarding the former, $S$. hystrix colonies of HWN were characterized by 1.4 -fold higher protein/DNA ratios than colonies of the same genotype and Symbiodinium assemblages of $\mathrm{HBH}$. It should be mentioned that, despite this difference, equal quantities of protein were loaded into all $2 \mathrm{D}$ gels. In contrast, $p s I$ mRNA expression was 1.5-fold higher in Symbiodinium (clade C [15]) populations within corals of $\mathrm{HBH}$. Although PERMANOVA did not detect a multivariate effect of site of origin across the 23 response variables (Table 1), it is possible that a hypothesis-neutral, proteomics-based approach could nevertheless uncover site-related differences in coral proteo-biology; such was indeed the case, and these findings are discussed in detail below.

\subsection{D + MS}

Of the 6 and 3 protein spots concentrated at higher levels by samples of HWN (Figure 2(a)) and $\mathrm{HBH}$ (Figure 2(b)), respectively, 6 and 1, respectively, were uniquely synthesized by corals of one site of origin and not the other; two DCPs were additionally isolated from the representative $\mathrm{HBH}$ gel (Figure 2(b)). From the $6 \mathrm{HWN}>\mathrm{HBH}$ and $3 \mathrm{HBH}>\mathrm{HWN}$ protein spots, 38 (Table 2) and 15 (Table 3) proteins, respectively, were identified with MS-SCAN using the $S$. hystrix-Symbiodinium transcriptome as a reference database (Figure 3). Regarding the compartmental breakdown of all 53 proteins identified (Figure 3(a)), 55 and $38 \%$ were of host coral and Symbiodinium origin, respectively. This 1.4:1 ratio did not differ significantly from the 1.8:1 mRNA ratio of this coral [17] ( $z$-test, $P>0.05)$, nor did it differ from the 1.6:1 host/Symbiodinium DCP ratio of another proteomic study of $S$. hystrix [17] (2-sample proportion test, $P>0.05$ ).

With respect to the functional breakdown of all 49 proteins that could be assigned a compartment of origin (Figure $3(\mathrm{~d})$ ), nearly half aligned to proteins that had not been characterized. Of the remaining 28 proteins (57\%) that did 


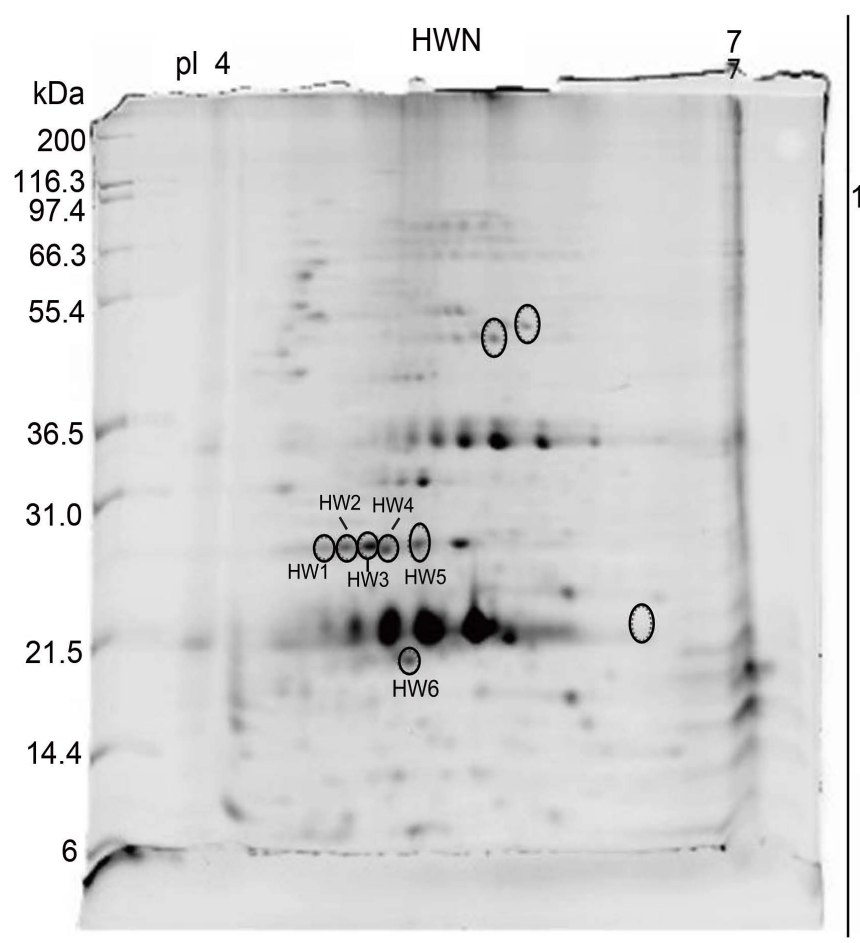

(a)

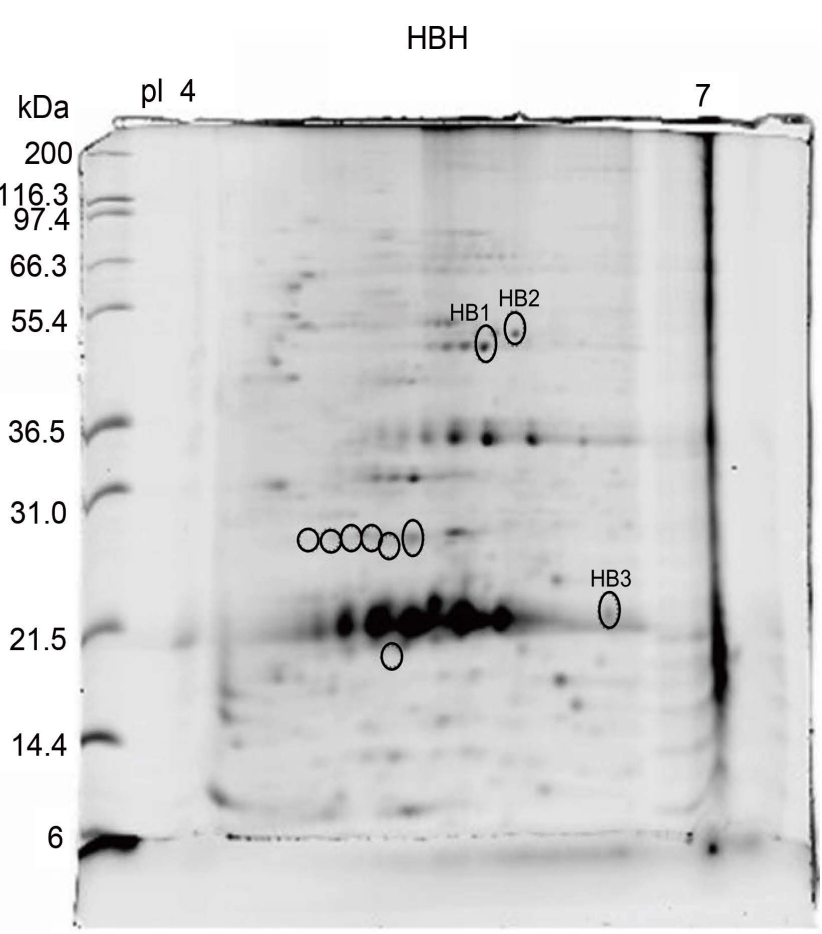

(b)

Figure 2. Representative two-dimensional (2D) protein gels from Seriatopora hystrix colonies sampled from Houwan (HWN; (a)) and Houbihu (HBH; (b)). The x- and y-axes represent the isoelectric point (pI; 4 - 7) and molecular weight (6 - 200 $\mathrm{kDa}$ ), respectively. Protein spots encircled and given a code (e.g., "HW1") were removed from the gel, digested, purified, and sequenced with mass spectrometry. Matched spots in the opposing gel (i.e., same molecular weight and pI) have been encircled to highlight their differential concentrations between sites.

align to characterized proteins, the dominant functional categories were cytoskeleton, stress response, transport, and transcription. Of the $14 \mathrm{HBH}>\mathrm{HWN}$ DCPs (Figure 3(e)), cytoskeleton and the stress response were the most represented categories, and proteins involved in the stress response were significantly more likely to be documented at higher levels by corals of HBH (22\% of the differentially expressed proteome) than conspecifics of HWN (Figure 3(f); $3 \%$; 2 -sample proportion test, $P<0.05$ ). For the $35 \mathrm{HWN}>\mathrm{HBH}$ DCPs (Figure $3(\mathrm{f})$ ), proteins involved in transcription and transport were instead of higher proportional abundance.

\subsection{Host Coral and Symbiodinium Differentially Concentrated Proteomes}

When looking only at the 29 host coral DCPs (Figure 3(g)), proteins involved in the stress response, cytoskeleton, and transcription were most abundant. As when the host and Symbiodinium data were pooled (Figure 3(d)-(f); discussed above), the former process was proportionally more abundant in the $\mathrm{HBH}>$ HWN proteome (Figure 3(h)); $22 \%$ of the $9 \mathrm{HBH}>\mathrm{HWN}$ and $0 \%$ of the 20 HWN $>$ HWN host DCPs were involved in the stress response (Figure 3(i); 2-sample proportion test, $P<0.05)$. Instead, transport and transcription were 


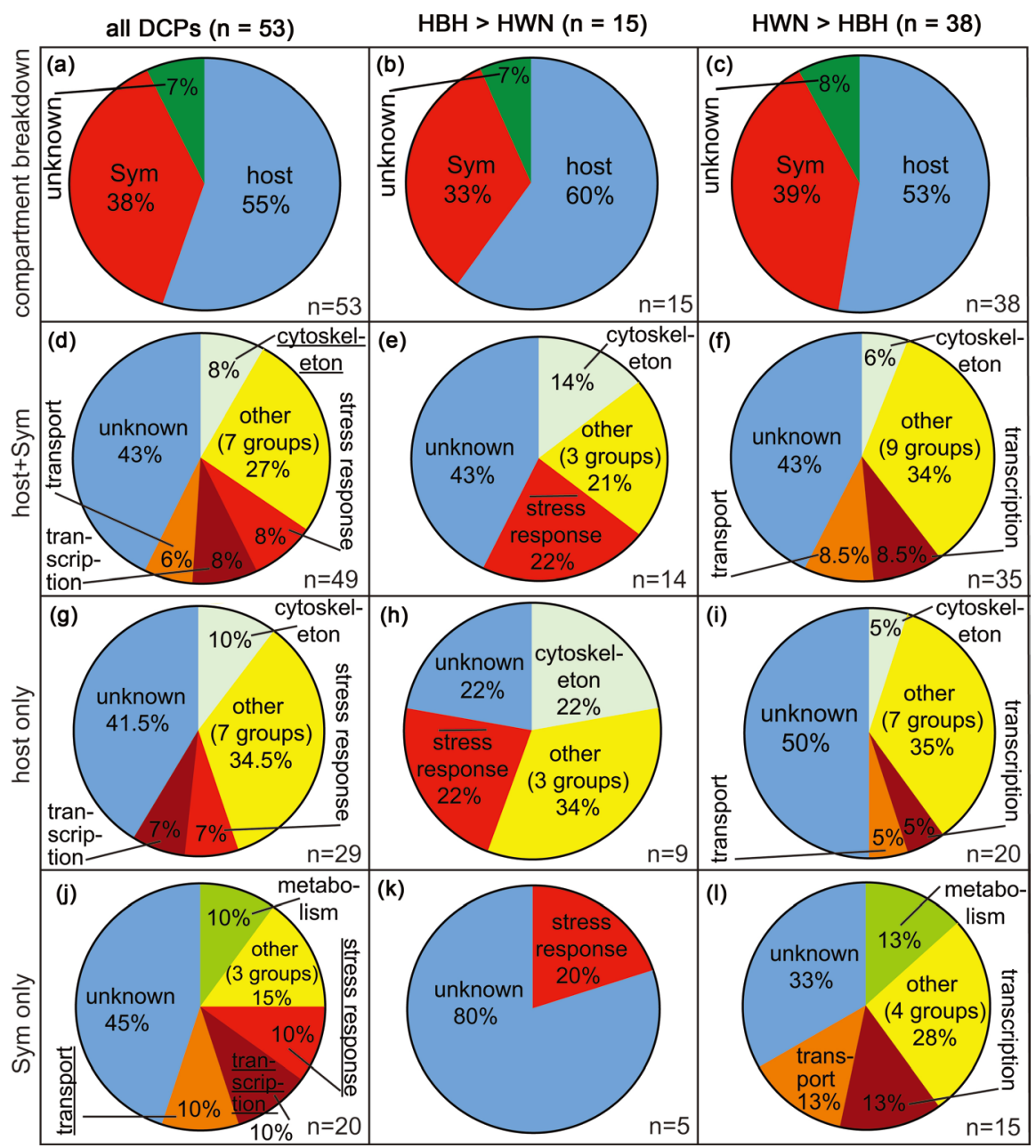

Figure 3. Pie graphs depicting compartmental and functional breakdown of proteins whose concentrations differed in Seriatopora hystrix colonies from two study sites: Houbihu (HBH; upwelling site) and Houwan (HWN; non-upwelling site). The compartmental breakdown of all uniquely synthesized (USPs) and differentially concentrated proteins (DCPs) has been shown for all DCPs + USPs (a), as well as for those HBH > HWN ((b); see Table 3.) and HWN > HBH ((c); see Table 2.) DCPs. Similarly, the host + Symbiodinium (Sym) DCPs (d)-(f), host DCPs only (g)-(i), and Sym DCPs only (j)-(l) have been presented across all DCPs $((\mathrm{d}),(\mathrm{g})$, and (j), respectively), the $\mathrm{HBH}>\mathrm{HWN}$ DCPs only ((e), (h), and (k), respectively), and the HWN > HBH DCPs only ((f), (i), and (l), respectively). When a functional category was represented at a significantly different proportion between the $\mathrm{HBH}>\mathrm{HWN}$ and $\mathrm{HWN}>\mathrm{HBH}$ proteomes, a bar has been placed over the category name in the proteome in which the value was higher. When the proportions of the host + Sym (d) and Sym functional categories ( $j$ ) were significantly higher than in their respective proportions in the 117-protein host + Sym and 42-protein Sym-only stable vs. variable temperature proteomes of Mayfield et al. [17], respectively, the functional category name has been underlined. No functional categories differed in proportional abundance between the 29 host coral DCPs uncovered herein and the 75 found to be differentially concentrated between stable and variable temperature treatments in Mayfield et al. [17].

the most numerically dominant functional categories in the $\mathrm{HWN}>\mathrm{HBH}$ differentially concentrated host coral proteome (Figure 3(i)). 
Table 2. The 38 proteins whose concentrations were higher in corals of the non-upwelling control site: Houwan (HWN). Spots 1, 2, 3, 4, 5, and 6 in the left-most column correspond to spots "HW1," "HW2," "HW3," "HW4," "HW5," and "HW6," respectively, in Figure 2(a); all were found only in the three HWN gels (and therefore in none of the three Houbihu [HBH] gels). The average coverage of $15 \pm 13 \%$ (std. dev.) did not differ significantly from that of the 15 differentially concentrated proteins found within the $3 \mathrm{HBH}>\mathrm{HWN}$ spots $(14 \pm 9 \%$ [std. dev.]; Table 3; student's $t$-test, $P>0.05)$. Contigs denoted by asterisks were associated with congruency between mRNA expression and protein concentration. The host/Symbiodinium (Sym) ratio of 20/15 (1.3:1) did not differ significantly from the $\mathrm{HBH}>\mathrm{HWN}$ ratio of $9 / 5$ (1.8:1; Table 3; 2-sample proportion test, $P>0.05)$, nor did it differ from the Seriatopora hystrix/Sym mRNA ratio of 1.8:1 [17] ( $Z$-test, $P>0.05$ ). For the peptide sequences, please see Table S1.

\begin{tabular}{|c|c|c|c|c|c|}
\hline $\begin{array}{c}\text { Spot } \\
(s)\end{array}$ & Compartment & Contig & Identity & $\begin{array}{l}\text { Functional } \\
\text { category }\end{array}$ & $\begin{array}{l}\text { Coverage } \\
(\%)\end{array}$ \\
\hline 1 & host & c71519_g1 & putative transcription factor Ovo-like 1 & transcription & 13 \\
\hline 1 & host & c32821_g1 & leucine-rich repeat \& IQ domain-containing protein 1 & unknown & 9 \\
\hline 1 & host & c79274_g3 & von Willebrand factor D \& EGF domain-containing protein & unknown & 8 \\
\hline 1 & Sym & c146943_g1 & ubiquitin-40S ribosomal protein $\mathrm{S} 27 \mathrm{a}$ & stress response & 35 \\
\hline 1 & Sym & c30229_g1 & unknown & unknown & 25 \\
\hline 1 & Sym & c288_g1 & adenylate cyclase & metabolism & 6 \\
\hline 2 & host & c73482_g1 & unknown & unknown & 16 \\
\hline 2 & host & c63186_g1 & unknown & unknown & 12 \\
\hline 2 & host & c69424_g1* & unknown & unknown & 12 \\
\hline 2,5 & host & c79716_g1 & debrin-like & $\begin{array}{l}\text { cell migration/ } \\
\text { actin binding }\end{array}$ & 8 \\
\hline 3 & host & c86107_g1 ${ }^{\mathrm{a}}$ & unknown & unknown & 19 \\
\hline $3-5$ & host & c65959_g1 & Rho GDP-dissociation inhibitor 1 & cytoskeleton & 16 \\
\hline 3 & host & c69652_g1 & unknown & unknown & 8 \\
\hline 3 & host & c76783_g1 ${ }^{\mathrm{a}}$ & serine/arginine repetitive matrix protein 2 & RNA processing & 7 \\
\hline 3 & host & c80461_g1 & $\begin{array}{l}\text { voltage-dependent R-type calcium channel } \\
\text { subunit alpha-1E-like isoform X2 }\end{array}$ & transport & 1 \\
\hline 3 & Sym & c75440_g1 ${ }^{\mathrm{b}}$ & fucoxanthin-chlorophyll a-c binding protein & photosynthesis & 24 \\
\hline 3 & Sym & c28876_g1 & unknown & unknown & 17 \\
\hline 3 & Sym & c192890_g1 & $\begin{array}{l}\text { bestrophin/alpha-ketoglutarate-dependent } \\
\text { dioxygenase alkB-like }\end{array}$ & transport & 16 \\
\hline 3 & Sym & c147855_g1 & hippocalcin-like protein 1 & transport & 13 \\
\hline 3 & Sym & c117310_g1 & alpha-1,2-mannosyltransferase ALG9 & metabolism & 6 \\
\hline 4 & host & c62634_g1 & protamine & DNA stabilization & 14 \\
\hline 4 & host & c80550_g3 & Prolow-density lipoprotein receptor-related protein 1 & endocytosis & 3 \\
\hline 5 & host & c167493_g1 & unknown & unknown & 63 \\
\hline 5 & host & c168524_g1 & short-chain collagen $\mathrm{C} 4$ & structural & 22 \\
\hline 5 & host & c170150_g1 & unknown & unknown & 16 \\
\hline 5 & host & c77868_g2 ${ }^{\mathrm{a}}$ & eukaryotic translation initiation factor 3 subunit A-like & translation & 12 \\
\hline 5 & host & c72431_g1 & Schlafen family member 5 & cell differentiation & 3 \\
\hline 5 & Sym & c51777_g1 & unknown & unknown & 14 \\
\hline 5 & Sym & c97047_g1 & unknown & unknown & 10 \\
\hline 5 & Sym & c13654_g1* & ankyrin repeat domain-containing protein 50 & unknown & 4 \\
\hline
\end{tabular}


Continued

\begin{tabular}{|c|c|c|c|c|c|}
\hline $\begin{array}{l}\text { Spot } \\
\text { (s) }\end{array}$ & Compartment & Contig & Identity & $\begin{array}{c}\text { Functional } \\
\text { category }\end{array}$ & $\begin{array}{c}\text { Coverage } \\
(\%)\end{array}$ \\
\hline 5 & Sym & c52097_g1 & DEAD-box ATP-dependent RNA helicase 35 & RNA processing & 3 \\
\hline 5 & unknown & c46638_g1 & unknown & unknown & 51 \\
\hline 5 & unknown & c45226_g1 & unknown & unknown & 33 \\
\hline 5 & unknown & c41865_g1* & unknown & unknown & 18 \\
\hline 6 & host & c52240_g1 & unknown & unknown & 14 \\
\hline 6 & Sym & c29807_g1 & serine/threonine protein kinase pelle & $\begin{array}{c}\text { signal } \\
\text { transduction }\end{array}$ & 3 \\
\hline 6 & Sym & c37817_g1 & unknown & unknown & 3 \\
\hline 6 & Sym & c48738_g1 & DNA topoisomerase I & DNA replication & 3 \\
\hline
\end{tabular}

${ }^{\mathrm{a}}$ Maintained at lower concentrations in corals exposed to variable temperature regimes [17]; ${ }^{\mathrm{b}}$ Closely related to a protein documented at lower concentrations in corals exposed to variable temperature regimes [17].

Table 3. The 15 proteins whose concentrations were higher in corals of the upwelling site: Houbihu (HBH). Spots 1, 2, and 3 in the left-most column correspond to spots "HB1," "HB2," and "HB3," respectively, in Figure 2(b). Only the latter spot was unique to the HBH gels; spots HB1 and HB2 were concentrated at higher levels in the HBH gels than the HWN gels and so were differentially concentrated proteins (DCPs) rather than uniquely synthesized proteins (USPs). Contigs denoted by asterisks were associated with congruency between mRNA expression and protein concentration. The host/Symbiodinium (Sym) DCP + USP ratio of $9 / 5$ (1.8:1) was the same as the Seriatopora hystrix/Sym mRNA ratio [17] (1.8:1; $z$-test, $P>0.05)$. For the peptide sequences, please see Table S1.

\begin{tabular}{|c|c|c|c|c|c|}
\hline Spot & Compartment & Contig & Identity & Functional category & $\begin{array}{c}\text { Coverage } \\
(\%)\end{array}$ \\
\hline $1(\mathrm{DCP})$ & host & c69816_g1 & actin & cytoskeleton & 27 \\
\hline 1 & host & c41229_g1 & unknown & unknown & 22 \\
\hline 1 & host & c58883_g1* & O-aminophenol oxidase & stress response & 11 \\
\hline 1 & host & c80336_g3 & RIMS-binding protein & neurotransmission & 9 \\
\hline 1 & host & c76524_g1 & $\begin{array}{l}\text { RNA polymerase-associated } \\
\text { protein CTR9-like }\end{array}$ & RNA processing/editing & 4 \\
\hline 1 & intermediate & c36639_g1 & RNA recognition motif (RRM) superfamily & RNA processing/editing & 8 \\
\hline $2(\mathrm{DCP})$ & host & c64389_g2 & gelsolin-like & cytoskeleton & 27 \\
\hline 2 & host & c59669_g2 & unknown & unknown & 10 \\
\hline 2 & Sym & c103934_g1 & unknown & unknown & 15 \\
\hline 2 & Sym & c185341_g1 & unknown & unknown & 13 \\
\hline 2 & Sym & c61072_g1 & HSPB1-associated protein 1-like & stress response & 10 \\
\hline 3 (USP) & host & c62707_g1 ${ }^{\mathrm{a}}$ & beta-gamma crystallin & stress response & 34 \\
\hline 3 & host & c108872_g1 & protein split ends isoform $\mathrm{X} 1$ & transcriptional repression & 12 \\
\hline 3 & Sym & c31796_g1 & unknown & unknown & 21 \\
\hline 3 & Sym & c37656_g1 & unknown & unknown & 4 \\
\hline
\end{tabular}

${ }^{a}$ Maintained at lower concentrations in corals exposed to variable temperature regimes [17].

In general, the same functional categories differed in proportional abundance between sites of origin for Symbiodinium (Figure 3(j)): stress response, transcription, and transport. However, the Symbiodinium differentially concentrated proteome also featured proteins involved in metabolism. When compared to 
another study performed with Taiwanese $S$. hystrix samples [16] [17], the Symbiodinium proteome sequenced herein featured significantly higher proportions of proteins involved in the stress response, transport, and transcription (2-sample proportion tests, $P<0.05)$. In the stable vs. variable temperature experiment, on the other hand, proteins associated with lipid bodies and mRNA processing were more likely to be maintained at different levels by Symbiodinium populations (2-sample proportion tests, $P<0.05$ ).

Only five Symbiodinium proteins were identified across the three $\mathrm{HBH}>$ HWN protein spots, and only one could be identified with confidence (Figure $3(\mathrm{k})$ ): a stress-associated HSPB1-associated protein 1-like protein was concentrated at higher levels in Symbiodinium from corals of HBH (Table 3). In contrast, the majority of the $15 \mathrm{HWN}>\mathrm{HBH}$ Symbiodinium DCPs could be identified with confidence (Figure 3(1)), and these proteins were involved in metabolism, transport, and transcription. No functional category differed in proportional abundance between host and Symbiodinium for the HBH > HWN or HWN > $\mathrm{HBH}$ differentially expressed proteomes.

\subsection{Congruency between mRNA Expression and Protein Concentration}

The congruency between mRNA and protein expression did not differ between the two compartments of the $S$. hystrix-Symbiodinium endosymbiosis (2-sample proportion tests, $P>0.05)$. Specifically, 2 of the 29 host coral molecules $(7 \%)$ and 1 of the 20 Symbiodinium molecules (5\%) demonstrated congruency between mRNA expression and protein concentration. These three molecules included 1) a host $\mathrm{O}$-aminophenol oxidase involved in the oxidative stress response (the lone $\mathrm{HBH}>\mathrm{HWN}$ molecule demonstrating congruency between mRNA and protein expression; 7\%; Table 3), 2) one host coral molecule of unknown function (HWN > HBH; Table 2), and 3) one Symbiodinium molecule of unknown function (HWN > HBH; Table 2). In addition, one HWN $>$ HBH USP of unknown cellular origin (Table 2) also demonstrated congruency between mRNA expression and protein concentration. The overall mRNA vs. protein congruency of $7.5 \%$ (4/53) was significantly higher than that of another study performed with Taiwanese $S$. hystrix samples (2-sample proportion test, $P<$ 0.05); Mayfield et al. [17] found only 2 molecules out of 167 total $(<2 \%)$ that demonstrated congruency between mRNA expression and protein concentration. A more detailed comparison with this only other proteomic assessment of S. hystrix [17] can be found below.

\subsection{Comparison with a Stable vs. Variable Temperature Regime Study Carried out with $S$. hystrix}

Besides a host coral beta-gamma crystallin protein, only three additional proteins were found to be differentially concentrated between sites of origin herein and between stable and variable temperature treatments in $\mathcal{S}$. hystrix nubbins made from these same colonies by Mayfield et al. [17]. All three proteins 
were of host coral origin, though only two could be identified with confidence: a serine-arginine repetitive matrix protein (RMP) involved in mRNA processing and a translation factor known as eukaryotic translation initiation factor 3 subunit A-like. The serine-arginine RMP was one of only four DCPs uncovered herein involved in mRNA processing and editing (7.5\%), the most temperature-sensitive cellular process documented previously in $S$. hystrix [17] $(16 \%)$. In contrast to the variable temperature study, proteins whose concentrations differed between the two study sites herein were more likely to be involved in the stress response, transcription, transport, and the cytoskeleton.

\section{Discussion}

\subsection{The Environmental Physiology of S. hystrix in Southern Taiwan}

Cell and molecular biology-driven approaches have aided in developing our understanding of both the fundamental biology of anthozoan-dinoflagellate endosymbioses [31] [32] [33] [34], as well as their environmental physiology [35] [36] [37]. Herein we utilized a differential proteomics approach to uncover proteins whose concentrations differed between corals of an upwelling site $(\mathrm{HBH})$ and a non-upwelling site $(\mathrm{HWN})$. In addition to the difference in the mean monthly temperature range between these two sites uncovered in prior works (e.g., [12]), a meta-analysis of previously published data conducted herein also revealed significant differences in silicate concentrations, suspended solid levels, and turbidity between them; specifically, these parameters were all significantly higher at $\mathrm{HBH}$. As the PAR levels reaching the sampled corals were identical at each site, the elevated turbidity and suspended solid levels at $\mathrm{HBH}$ did not evidently result in a decrease in PAR reaching the sampled $S$. hystrix colonies. However, it is possible that such suspended solids affected other wavelengths of light that were not measured; for instance, high levels of suspended particulate matter lead to the attenuation of ultraviolet radiation (UVR) in wastewater [38].

If diminished UVR levels were reaching the HBH $S$. hystrix colonies, then they could be hypothesized to be at lower risk of high temperature + UVR-induced bleaching [39]. In fact, relatively more proteins in the $\mathrm{HBH}>\mathrm{HWN}$ differentially expressed host + Symbiodinium proteome (22\%) were involved in the stress response compared to the 35-protein $\mathrm{HWN}>\mathrm{HBH}$ proteome (3\%). These three, presumably stress-targeted $\mathrm{HBH}>\mathrm{HWN}$ proteins included two host coral proteins, beta-gamma crystallin and O-aminophenol oxidase, as well as the Symbiodinium protein known as HSPB1-associated protein 1-like. Beta-gamma crystallin, which has only ever been hypothesized to be involved in the stress response (as well as calcium binding [40]), was actually found to be down-regulated in $S$. hystrix specimens exposed to a variable temperature regime for one week [17] and represents one of only four proteins found to differ in concentration between sites of origin herein and across temperature treatments in Mayfield et al. [17]; as such, and in reiterating the rec- 
ommendation of Meyer et al. [41], we advocate that the role of beta-gamma crystallin in coral thermal adaptation be more thoroughly characterized in future works.

Given the fact that mean monthly temperature range, silicate concentrations, and suspended solid levels and turbidity were all higher at $\mathrm{HBH}$ (the upwelling site), it is tempting to speculate that the relatively higher number of stress response-associated proteins within the $\mathrm{HBH}>\mathrm{HWN}$ proteome is indicative of sub-lethal levels of cellular stress in corals of $\mathrm{HBH}$. However, the physiological performance of these corals did not differ from those of HWN ([12] [15] and Table 1). This may mean, in contrast, that such constitutively elevated stress protein levels instead represent "front-loading" [25] [42], whereby stress proteins are maintained at high intracellular concentrations such that the molecular machinery requisite for dealing with large shifts in the abiotic environment (e.g., an upwelling event in the case of corals of $\mathrm{HBH}$ ) is engaged at any given time. This strategy is relatively uncommon in nature given the high energetic expense of being constitutively "stressed" at all times [43], though it does characterize the cellular biology of some intertidal invertebrates [44]. By exposing corals from both study sites to variable temperature regimes and elevated suspended solid levels in the laboratory, it may ultimately be determined whether the protein expression signatures of corals of $\mathrm{HBH}$ documented herein are resultant of cellular stress due to, for instance, direct impacts of sediments with coral tissues (sensu [45] [46]), or, alternatively, represent a protective response to counter future environmental change. If healthy corals indeed constitutively maintain high cellular concentrations of stress-associated proteins, as has also been documented in the most-remote reaches of French Polynesia [35], then this may complicate the interpretation of data derived from molecular biomarker panels aimed at assessing coral health; in other words, are high concentrations of molecular chaperones and other stress proteins indicative of healthy corals or stressed ones?

\subsection{The Role of Osmoregulation in Coral Acclima(tiza)tion to Environmental Change}

Osmoregulation has been hypothesized to be the crux of the coral stress and bleaching response [47]. This theory stems from the fact that high temperatureand light-induced photoinhibition [48] would presumably result in a reduction in osmolyte flux from Symbiodinium to host. This would lead to a drop in osmotic pressure in the endosymbiotic gastrodermal cell [49], which would manifest in changes in cytoskeletal architecture [50]. This may explain why a large number of host cytoskeleton-associated proteins were differentially concentrated between corals of the two sites. Specifically, actin and gelsolin (which is involved in actin assembly/disassembly) were synthesized at higher levels by corals of $\mathrm{HBH}$. The fact that these corals are more likely to undergo osmotic pressure fluctuations as a result of upwelling-induced temperature changes may explain why they constitutively synthesize larger quantities of gelsolin, in particular, as 
this protein acts in cytoskeleton rebuilding. Not surprisingly then, genes encoding proteins involved in the cytoskeleton have found to be differentially expressed in corals exposed to elevated temperatures [51]. Given these findings, as well as the fact that osmoregulation is the most energetically expensive task a cell undertakes, the role of osmoregulation in the coral thermal stress response should be more thoroughly characterized in future works. It should be noted here that, due to the rigid cell walls of Symbiodinium, the osmotic stress associated with temperature + UVR stress-derived photoinhibition mentioned above is not hypothesized to dramatically affect Symbiodinium cell volume [47]; therefore, it is unsurprising that no Symbiodinium cytoskeleton proteins were uncovered herein.

\subsection{Congruency between mRNA Expression and Protein Concentration}

Unfortunately, it has become commonplace in the coral biology field to make conjectures about protein behavior based on mRNA expression data alone (sen$s u$ [52] [53]), despite the fact that mRNA vs. protein congruency has been found to be as low as $0 \%$ in Symbiodinium populations within $S$. hystrix nubbins of another study [17]. Likewise, the degree of congruency between mRNA expression and protein concentration was markedly low herein; only 4 of the 53 DCPs uncovered were associated with an mRNA whose expression also differed significantly between sites of origin (7.5\%). One such molecule, the host coral O-aminophenol oxidase, was discussed above in the context of the coral stress/environmental acclimation response. Given the low congruency between mRNA expression and protein concentration in both this study (7.5\%) and others (2\% in Mayfield et al. [17] and 10.5\% in Mayfield et al. [26]), we advise that those researchers looking to model the response of anthozoan-dinoflagellate endosymbioses to environmental change instead exploit proteomics-based approaches in their experiments; unlike the mRNAs that encode them, proteins actually enact physiological changes in cells and are likely to play key roles in thermal acclimation in both coral hosts [54] and their in hospite Symbiodinium populations.

\section{Acknowledgements}

The authors would like to thank Dr. Yu-Bin Wang for developing the MS-SCAN software and implementing it on the $S$. hystrix-Symbiodinium transcriptome server, as well as Drs. Peter Edmunds and Tung-Yung Fan for fruitful discussions on the eco-physiology of corals of Southern Taiwan. This work was funded by the United States National Science Foundation (postdoctoral research fellowship to ABM; OISE-0852960) and the Khaled bin Sultan Living Oceans Foundation (postdoctoral research fellowship to ABM).

\section{References}

[1] Hoegh-Guldberg, O., Mumby, P.J., Hooten, A.J., Steneck, R.S., Greenfield, P., Go- 
mez, E., Harvell, C.D., Sale, P.F., Caldeira, K., Knowlton, N., Eakin, C.M., Iglesias-Prieto, R., Muthiga, N., Bradbury, R.H., Dubi, A. and Hatziolos, M.E. (2007) Coral Reefs under Rapid Climate Change and Ocean Acidification. Science, 318, 1737-1742. https://doi.org/10.1126/science.1152509

[2] Putnam, H.M., Barott, K., Ainsworth, T.D. and Gates, R.D. (2017) The Vulnerability and Resilience of Reef-Building Corals. Current Biology, 27, R528-R540. https://doi.org/10.1016/j.cub.2017.04.047

[3] Brown, B.E. (1997) Coral Bleaching: Causes and Consequences. Coral Reefs, 16, s129-s138. https://doi.org/10.1007/s003380050249

[4] Gates, R.D. and Edmunds, P.J. (1999) The Physiological Mechanisms of Acclimatization in Tropical Reef Corals. Integrative and Comparative Biology, 39, 30-43.

https://doi.org/10.1093/icb/39.1.30

[5] Barshis, D.J., Stillman, J.H., Gates, R.D., Toonen, R.J., Smith, L.W. and Birkeland, C. (2010) Protein Expression and Genetic Structure of the Coral Porites lobata in an Environmentally Extreme Samoan Back Reef: Does Host Genotype Limit Phenotypic Plasticity? Molecular Ecology, 19, 1705-1720.

https://doi.org/10.1111/j.1365-294X.2010.04574.x

[6] Krueger, T., Horwitz, N., Bodin, J., Giovani, M.E., Escrig, S., Meibom, A. and Fine, M. (2017) Common Reef-Building Coral in the Northern Red Sea Resistant to Elevated Temperature and Acidification. Royal Society Open Science, 4, Article ID: 170038. https://doi.org/10.1098/rsos.170038

[7] Mayfield, A.B., Chen, M., Meng, P.J., Lin, H.J., Chen, C.S. and Liu, P.J. (2013) The Physiological Response of the Reef Coral Pocillopora damicornis to Elevated Temperature: Results from Coral Reef Mesocosm Experiments in Southern Taiwan. $\mathrm{Ma}$ rine and Environmental Research, 86, 1-11. https://doi.org/10.1016/j.marenvres.2013.01.004

[8] Mayfield, A.B., Fan, T.Y. and Chen, C.S. (2013) Physiological Acclimation to Elevated Temperature in a Reef-Building Coral from an Upwelling Environment. Coral Reefs, 32, 909-921. https://doi.org/10.1007/s00338-013-1067-4

[9] Mayfield, A.B., Fan, T.Y. and Chen, C.S. (2013) Real-Time PCR-Based Gene Expression Analysis in the Model Reef-Building Coral Pocillopora damicornis. Insight from a Salinity Stress Study. Platax, 10, 1-29.

[10] Mayfield, A.B., Chen, C.S. and Liu, P.J. (2014) Decreased Green Fluorescent Protein-Like Chromoprotein Gene Expression in Specimens of the Reef-Building Coral Pocillopora damicornis Undergoing High Temperature-Induced Bleaching. Platax, 11, 1-23.

[11] Putnam, H.M. and Edmunds, P.J. (2011) The Physiological Response of Reef Corals to Diel Fluctuations in Seawater Temperature. Journal of Experimental Marine Biology and Ecology, 396, 216-223. https://doi.org/10.1016/j.jembe.2010.10.026

[12] Mayfield, A.B., Chan, P.H., Putnam, H.M., Chen, C.S. and Fan, T.Y. (2012) The Effects of a Variable Temperature Regime on the Physiology of the Reef-Building Coral Seriatopora hystrix: Results from a Laboratory-Based Reciprocal Transplant. Journal of Experimental Biology, 215, 4183-4195. https://doi.org/10.1242/jeb.071688

[13] Chen, C.T.A., Hsing, L.Y., Liu, C.L. and Wang, S.L. (2004) Degree of Nutrient Consumption of Upwelled Water in the Taiwan Strait Based on Dissolved Organic Phosphorus or Nitrogen. Marine Chemistry, 87, 73-86. https://doi.org/10.1016/j.marchem.2004.01.006

[14] Mayfield, A.B., Fan, T.Y. and Chen, C.S. (2013) The Physiological Impact of ex Situ Transplantation on the Taiwanese Reef-Building Coral Seriatopora hystrix. Journal 
of Marine Biology, 2013, Article ID: 569369. https://doi.org/10.1155/2013/569361

[15] Mayfield, A.B., Chen, Y.H., Dai, C.F. and Chen, C.S. (2014) The Effects of Temperature on Gene Expression in the Reef-Building Coral Seriatopora hystrix. Insight from Aquarium Studies in Southern Taiwan. International Journal of Marine Science, 4, 1-23. https://doi.org/10.5376/ijms.2014.04.0050

[16] Mayfield, A.B., Chen, Y.J., Lu, C.Y. and Chen, C.S. (2016) Proteins Responsive to Variable Temperature Exposure in the Reef-Building Coral Seriatopora hystrix. In: Ortiz, S., Ed., Coral Reefs. Ecosystems, Environmental Impact and Current Threats, NOVA Publishing, New York, 1-60.

[17] Mayfield, A.B., Wang, Y.B., Chen, C.S., Chen, S.H. and Lin, C.Y. (2016) Dual-Compartmental Transcriptomic + Proteomic Analysis of a Marine Endosymbiosis Exposed to Environmental Change. Molecular Ecology, 25, 5944-5958. https://doi.org/10.1111/mec.13896

[18] Peng, S.E., Chen, W.N.U., Chen, H.K., Lu, C.Y., Mayfield, A.B., Fang, L.S. and Chen, C.S. (2011) Lipid Bodies in Coral-Dinoflagellate Endosymbiosis: Ultrastructural and Proteomic Analyses. Proteomics, 17, 3540-3455. https://doi.org/10.1002/pmic.201000552

[19] Weston, A.J., Dunlap, W.C., Shick, J.M., Klueter, A., Iglic, K., Vukelic, A., Starcevic, A., Ward, M., Wells, M.L., Trick, C.G. and Long, P.F. (2012) A Profile of an Endosymbiont-Enriched Fraction of the Coral Stylophora pistillata Reveals Proteins Relevant to Microbial-Host Interactions. Molecular and Cellular Proteomics, 11, M111.015487. https://doi.org/10.1074/mcp.M111.015487

[20] Oakley, C.A., Ameismeier, M.F., Peng, L., Weis, V.M., Grossman, A.R. and Davy, S.K. (2016) Symbiosis Induces Widespread Changes in the Proteome of the Model Cnidarian Aiptasia. Cellular Microbiology, 18, 1009-1023. https://doi.org/10.1111/cmi.12564

[21] Weston, A.J., Dunlap, W.C., Beltran, V.H., Starcevic, A., Hranueli, D., Ward, M. and Long, P.F. (2015) Proteomics Links the Redox State to Calcium Signaling during Bleaching of the Scleractinian Coral Acropora microphthalma on Exposure to High Solar Irradiance and Thermal Stress. Molecular and Cellular Proteomics, 14, 585-595. https://doi.org/10.1074/mcp.M114.043125

[22] Liu, P.J., Meng, P.J., Liu, L.L., Wang, J.T. and Leu, M.Y. (2012) Impacts of Human Activities on Coral Reef Ecosystems of Southern Taiwan: A Long-Term Study. Marine Pollution Bulletin, 64, 1129-1135. https://doi.org/10.1016/j.marpolbul.2012.03.031

[23] Ribas-Deulofeu, L., Denis, V., De Palmas, S., Kuo, C.Y., Hsieh, H.J. and Chen, C.A. (2016) Structure of Benthic Communities along the Taiwan Latitudinal Gradient. PLoS ONE, 11, e0160601. https://doi.org/10.1371/journal.pone.0160601

[24] Tkachenko, K.S., Wu, B.J., Fang, L.S. and Fan, T.Y. (2007) Dynamics of a Coral Reef Community after Mass Mortality of Branching Acropora Corals and an Outbreak of Anemones. Marine Biology, 151, 185-194. https://doi.org/10.1007/s00227-006-0467-1

[25] Mayfield, A.B., Wang, L.H., Tang, P.C., Hsiao, Y.Y., Fan, T.Y., Tsai, C.L. and Chen, C.S. (2011) Assessing the Impacts of Experimentally Elevated Temperature on the Biological Composition and Molecular Chaperone Gene Expression of a Reef Coral. PLOS ONE, 6, e26529. https://doi.org/10.1371/journal.pone.0026529

[26] Mayfield, A.B., Chen, Y.J., Lu, C.Y. and Chen, C.S. (2018) The Proteomic Response of the Reef Coral Pocillopora acuta to Experimentally Elevated Temperature. PLoS ONE, 13, e0192001. https://doi.org/10.1371/journal.pone.0192001

[27] Mayfield, A.B. (2016) Uncovering Spatio-Temporal and Treatment-Derived Dif- 
ferences in the Molecular Physiology of a Model Coral-Dinoflagellate Mutualism with Multivariate Statistical Approaches. Journal of Marine Science and Engineering, 4, 63. https://doi.org/10.3390/jmse4030063

[28] Kim, S. and Pevzner, P.A. (2014) MS-GF+ Makes Progress towards a Universal Database Search Tool for Proteomics. Nature Communication, 5, 5277. https://doi.org/10.1038/ncomms6277

[29] Chiva, C., Ortega, M. and Sabido, E. (2014) Influence of the Digestion Technique, Protease, and Missed Cleavage Peptides in Protein Quantitation. Journal of Proteome Research, 13, 3979-3986. https://doi.org/10.1021/pr500294d

[30] Rudnick, P.A., Markey, S.P., Roth, J., Mirokhin, Y., Yan, X., Tchekhovskoi, D.V., Edwards, N.J., Thangudu, R.R., Ketchum, K.A., Kinsinger, C.R., Mesri, M., Rodriguez, H. and Stein, S. (2016) A Description of the Clinical Proteomic Tumor Analysis Consortium (CPTAC) Common Data Analysis Pipeline. Journal of Proteome Research, 15, 1023-1032. https://doi.org/10.1021/acs.jproteome.5b01091

[31] Mayfield, A.B., Hsiao, Y.Y., Fan, T.Y. and Chen, C.S. (2012) Temporal Variation in RNA/DNA and Protein/DNA Ratios in Four Anthozoan-Dinoflagellate Endosymbioses of the Indo-Pacific: Implications for Molecular Diagnostics. Platax, 9, 1-24.

[32] Chen, H.K., Song, S.N., Wang, L.H., Mayfield, A.B., Chen, Y.J., Chen, W.N.U. and Chen, C.S. (2015) A Compartmental Comparison of Major Lipid Species in a Coral-Symbiodinium Endosymbiosis: Evidence That the Coral Host Regulates Lipogenesis of Its Cytosolic Lipid Bodies. PLOS ONE, 10, e0132519. https://doi.org/10.1371/journal.pone.0132519

[33] Chen, W.N.U., Hsiao, Y.J., Mayfield, A.B., Young, R., Hsu, L., Chen, C.S. and Peng, S.E. (2016) Vertical Transmission of Heterologous Clade C Symbiodinium in a Model Anemone Infection System. Peer J, 4, e2358. https://doi.org/10.7717/peerj.2358

[34] Chen, H.K., Mayfield, A.B., Wang, L.H. and Chen, C.S. (2017) Coral Lipid Bodies as the Relay Center Interconnecting Diel-Dependent Lipidomic Changes in Different Cellular Compartments. Scientific Reports, 7, 3244. https://doi.org/10.1038/s41598-017-02722-z

[35] Mayfield, A.B., Chen, C.S., Dempsey, A.C. and Bruckner, A.W. (2016) The Molecular Ecophysiology of Closely Related Pocilloporids from the South Pacific: A Case Study from the Austral and Cook Islands. Platax, 13, 1-25.

[36] Mayfield, A.B., Chen, C.S. and Dempsey, A.C. (2017) Biomarker Profiling in Reef Corals of Tonga's Ha'apai and Vava'u Archipelagos. PLOS ONE, 12, e0185857. https://doi.org/10.1371/journal.pone.0185857

[37] Mayfield, A.B., Chen, C.S. and Dempsey, A.C. (2017) Identifying Corals Displaying Aberrant Behavior in Fiji's Lau Archipelago. PLoS ONE, 12, e0177267. https://doi.org/10.1371/journal.pone.0177267

[38] Cantwell, R.E. and Hofmann, R. (2011) Ultraviolet Absorption Properties of Suspended Particulate Matter in Untreated Surface Waters. Water Research, 45, 1322-1328. https://doi.org/10.1016/j.watres.2010.10.020

[39] Lesser, M.P. (1996) Elevated Temperatures and Ultraviolet Radiation Cause Oxidative Stress and Inhibit Photosynthesis in Symbiotic Dinoflagellates. Limnology and Oceanography, 41, 271-283. https://doi.org/10.4319/lo.1996.41.2.0271

[40] Lundgren, P., Vera, J.C., Peplow, L., Manel, S. and van Oppen, M.J.H. (2013) Genotype-Environment Correlations in Corals from the Great Barrier Reef. BMC Genetics, 14, 9. https://doi.org/10.1186/1471-2156-14-9 
[41] Meyer, E., Davies, S., Wang, S., Willis, B.L., Abrego, D., Juenger, T.E. and Matz, M.V. (2009) Genetic Variation in Responses to a Settlement Cue and Elevated Temperature in the Reef-Building Coral Acropora millepora. Marine Ecology Progress Series, 392, 81-92. https://doi.org/10.3354/meps08208

[42] Barshis, D.J., Ladner, J.T., Oliver, T.A., Seneca, F.O., Traylor-Knowles, N. and Palumbi, S.R. (2013) Genomic Basis for Coral Resilience to Climate Change. Proceedings of the National Academy of Sciences of the United States of America, 110, 1387-1392. https://doi.org/10.1073/pnas.1210224110

[43] Hochachka, P.W. and Somero, G.N. (2002) Biochemical Adaptation. Oxford University Press, Oxford.

[44] Dong, Y., Miller, L.P., Sanders, J.G. and Somero, G.N. (2008) Heat-Shock Protein 70 (Hsp70) Expression in Four Limpets of the Genus Lottia: Interspecific Variation in Constitutive and Inducible Synthesis Correlates with in Situ Exposure to Heat Stress. The Biological Bulletin, 215, 173-181. https://doi.org/10.2307/25470698

[45] Fabricius, K.E. (2005) Effects of Terrestrial Run of on the Ecology of Corals and Coral Reefs: Review and Synthesis. Marine Pollution Bulletin, 50, 125-146. https://doi.org/10.1016/j.marpolbul.2004.11.028

[46] Liu, P.J., Hsin, M.C., Huang, Y.H., Fan, T.Y., Meng, P.J., Lu, C.C. and Lin, H.J. (2015) Nutrient Enrichment Coupled with Sedimentation Favors Sea Anemones over Corals. PLoS ONE, 10, e0125175. https://doi.org/10.1371/journal.pone.0125175

[47] Mayfield, A.B. and Gates, R.D. (2007) Osmoregulation in Anthozoan-Dinoflagellate Symbiosis. Comparative Biochemistry and Physiology Part A: Molecular \& Integrative Physiology, 147, 1-10. https://doi.org/10.1016/j.cbpa.2006.12.042

[48] Jones, R.J., Hoegh-Guldberg, O., Larkum, A.W.D. and Schreiber, U. (1998) Temperature-Induced Bleaching of Corals Begins with Impairment of the $\mathrm{CO}_{2}$ Fixation Metabolism in Zooxanthellae. Plant, Cell and Environment, 21, 1219-1230. https://doi.org/10.1046/j.1365-3040.1998.00345.x

[49] Mayfield, A.B., Hsiao, Y.Y., Fan, T.Y., Chen, C.S. and Gates, R.D. (2010) Evaluating the Temporal Stability of Stress-Activated Protein Kinase and Cytoskeleton Gene Expression in the Pacific Corals Pocillopora damicornis and Seriatopora hystrix. Journal of Experimental Marine Biology and Ecology, 395, 215-222. https://doi.org/10.1016/j.jembe.2010.09.007

[50] Thirone, A.C.P., Speight, P., Zulys, M., Rotstein, O.D., Szaszi, K., Pedersen, S.F. and Kapus, A. (2009) Hyperosmotic Stress Induces Rho/Rho Kinase/LIM Kinase-Mediated Cofilin Phosphorylation in Tubular Cells: Key Role in the Osmotically Triggered F-Actin Response. American Journal of Physiology-Cell Physiology, 296, C463-C475. https://doi.org/10.1152/ajpcell.00467.2008

[51] Desalvo, M.K., Voolstra, C.R., Sunagawa, S., Schwarz, J., Stillman, J.H., Coffroth, M.A., Szmant-Froelich, A.M. and Medina, M. (2008) Differential Gene Expression during Thermal Stress and Bleaching in the Caribbean Coral Montastraea faveolata. Molecular Ecology, 17, 3952-3971. https://doi.org/10.1111/j.1365-294X.2008.03879.x

[52] Palumbi, S.R., Barshis, D.J., Traylor-Knowles, N. and Bay, R.A. (2014) Mechanisms of Reef Coral Resistance to Future Climate Change. Science, 344, 895-898. https://doi.org/10.1126/science.1251336

[53] Mayfield, A.B., Wang, Y.B., Chen, C.S., Chen, S.H. and Lin, C.Y. (2014) Compartment-Specific Transcriptomics in a Reef-Building Coral Exposed to Elevated Temperatures. Molecular Ecology, 23, 5816-5830. https://doi.org/10.1111/mec.12982

[54] Downs, C.A., Mueller, E., Phillips, S., Fauth, J.E. and Woodley, C.M. (2000) A Molecular Biomarker System for Assessing the Health of Coral (Montastrea faveolata) 
during Heat Stress. Marine Biotechnology, 2, 533-544.

https://doi.org/10.1007/s101260000038

[55] Mayfield, A.B., Hirst, M.B. and Gates, R.D. (2009) Gene Expression Normalization in a Dual-Compartment System: A Real-Time PCR Protocol for Symbiotic Anthozoans. Molecular Ecology Resources, 9, 462-470.

https://doi.org/10.1111/j.1755-0998.2008.02349.x

[56] Putnam, H.M., Mayfield, A.B., Fan, T.Y., Chen, C.S. and Gates, R.D. (2013) The Physiological and Molecular Responses of Larvae from the Reef-Building Coral Pocillopora damicornis Exposed to Near-Future Increases in Temperature \& $p \mathrm{CO}_{2}$. Marine Biology, 160, 2157-2173. https://doi.org/10.1007/s00227-012-2129-9 


\section{Supplemental Data-Peptide Sequences}

Table S1. "AA" = amino acids. "Sym" $=$ Symbiodinium. ${ }^{*}=$ two peptide sequences overlapped. ${ }^{\star *}=$ three peptide sequences overlapped.

\begin{tabular}{|c|c|c|c|}
\hline Name & $\begin{array}{l}\text { Length } \\
\text { (\#AA) }\end{array}$ & Sequence & Protein identity \\
\hline $\begin{array}{l}\mathrm{HBH}>\mathrm{HWN} \text { spot } 1 \text {, protein } 1 \\
\quad(\text { c41229_g1) }\end{array}$ & 39 & $\begin{array}{l}\text { AIYEMKKKLGVNIKFIHVVRNPFDNIATMVLQH } \\
\text { KAIKGR* }\end{array}$ & unknown host \\
\hline $\begin{array}{l}\mathrm{HBH}>\mathrm{HWN} \text { spot } 1 \text {, protein } 2 \\
\quad(\text { c58883_g1) }\end{array}$ & 30 & QLRRLGVKKKERRHARKLLKKELEPKKRIR* & host $\mathrm{O}$-aminophenol oxidase \\
\hline $\begin{array}{l}\text { HBH }>\text { HWN spot } 1 \text {, protein } 3 \text {, } \\
\text { peptide } 1 \text { (c69816_g1) }\end{array}$ & 21 & AGFAGDDAPRAVFPSIVGRPR* ${ }^{*}$ & host actin \\
\hline $\begin{array}{l}\text { HBH }>\text { HWN spot } 1 \text {, protein } 3 \text {, } \\
\text { peptide } 2 \text { (c69816_g1) }\end{array}$ & 12 & DSYVGDEAQSKR & \\
\hline $\begin{array}{l}\text { HBH }>\text { HWN spot } 1 \text {, protein } 3 \text {, } \\
\text { peptide } 3 \text { (c69816_g1) }\end{array}$ & 29 & IWHHTFYNELRVAPEEHPVLLTEAPLNPK* & \\
\hline $\begin{array}{l}\mathrm{HBH}>\mathrm{HWN} \text { spot } 1 \text {, protein } 3 \text {, } \\
\text { peptide } 4 \text { (c69816_g1) }\end{array}$ & 10 & GYSFTTTAER & \\
\hline $\begin{array}{l}\text { HBH }>\text { HWN spot } 1 \text {, protein } 3 \text {, } \\
\text { peptide } 5 \text { (c69816_g1) }\end{array}$ & 16 & SYELPDGQVITIGNER & \\
\hline $\begin{array}{l}\text { HBH }>\text { HWN spot } 1 \text {, protein } 3 \text {, } \\
\text { peptide } 6 \text { (c69816_g1) }\end{array}$ & 13 & QEYDESGPSIVHR & \\
\hline $\begin{array}{l}\text { HBH }>\text { HWN spot } 1 \text {, protein } 4, \\
\text { peptide } 1 \text { (c80336_g3) }\end{array}$ & 18 & QRAKDLAEHAKALLSKEK & host RIMS-binding protein \\
\hline $\begin{array}{l}\text { HBH }>\text { HWN spot } 1 \text {, protein } 4, \\
\text { peptide } 2 \text { (c80336_g3) }\end{array}$ & 19 & LEVSDVKCGLLTDECNKLK & \\
\hline $\begin{array}{c}\mathrm{HBH}>\mathrm{HWN} \text { spot } 1 \text {, protein } 5, \\
\text { peptide } 1 \text { (c36639_g1) }\end{array}$ & 22 & GHQHWDNNYWRKDDRRPSRYWR & \\
\hline $\begin{array}{l}\text { HBH }>\text { HWN spot } 1 \text {, protein } 5 \text {, } \\
\text { peptide } 2 \text { (c36639_g1) }\end{array}$ & 24 & QKRRRRRKMDETGQPQRHLKRRKR & $\begin{array}{l}\text { RNA recognition motif } \\
\text { superfamily }\end{array}$ \\
\hline $\begin{array}{c}\mathrm{HBH}>\mathrm{HWN} \text { spot } 1 \text {, protein } 6, \\
\text { peptide } 1 \text { (c76524_g1) } \\
\text { HBH }>\text { HWN spot } 1 \text {, protein } 6, \\
\text { peptide } 2 \text { (c76524_g1) }\end{array}$ & 29 & FFKHHNVEVLLYLARAYFKAGKLKECKQILLK & $\begin{array}{c}\text { host RNA } \\
\text { polymerase-associated } \\
\text { protein CTR9-like }\end{array}$ \\
\hline $\begin{array}{l}\mathrm{HBH}>\mathrm{HWN} \text { spot } 2 \text {, protein } 1 \text {, } \\
\text { peptide } 1 \text { (c64389_g2) }\end{array}$ & 13 & DSNLALFGSDLEK & host gelsolin-like \\
\hline $\begin{array}{c}\mathrm{HBH}>\mathrm{HWN} \text { spot } 2 \text {, protein } 1, \\
\text { peptide } 2 \text { (c64389_g2) }\end{array}$ & 14 & FYNGDSYIILNTYK & \\
\hline
\end{tabular}




\section{Continued}

\begin{tabular}{|c|c|c|c|}
\hline Name & $\begin{array}{l}\text { Length } \\
\text { (\#AA) }\end{array}$ & Sequence & Protein identity \\
\hline $\begin{array}{l}\mathrm{HBH}>\mathrm{HWN} \text { spot } 2 \text {, protein } 1, \\
\text { peptide } 3 \text { (c64389_g2) }\end{array}$ & 28 & ESTQDEYGTAAYKTVELDTLNDKPVQHR* & \\
\hline $\begin{array}{l}\mathrm{HBH}>\mathrm{HWN} \text { spot } 2 \text {, protein } 1, \\
\text { peptide } 4 \text { (c64389_g2) }\end{array}$ & 18 & KYFSQLELLTGGADSGFR & \\
\hline $\begin{array}{l}\mathrm{HBH}>\mathrm{HWN} \text { spot } 2 \text {, protein } 1, \\
\text { peptide } 5 \text { (c64389_g2) }\end{array}$ & 38 & $\begin{array}{l}\text { VTEVAYCKESITPDNVYVIDNGEEIYQINGSSSD } \\
\text { KDER }^{*}\end{array}$ & \\
\hline $\begin{array}{l}\mathrm{HBH}>\mathrm{HWN} \text { spot } 2 \text {, protein } 1, \\
\text { peptide } 6 \text { (c64389_g2) }\end{array}$ & 9 & AAQYCQSLK & \\
\hline $\begin{array}{l}\mathrm{HBH}>\mathrm{HWN} \text { spot } 2 \text {, protein } 1, \\
\text { peptide } 7 \text { (c64389_g2) }\end{array}$ & 46 & $\begin{array}{c}\text { EGGFGGLPSGDPDTEDPIDDDFEPTIKKISDASG } \\
\text { HLELSDTSGFSK }{ }^{*}\end{array}$ & \\
\hline $\begin{array}{l}\mathrm{HBH}>\mathrm{HWN} \text { spot } 2 \text {, protein } 1, \\
\text { peptide } 8 \text { (c64389_g2) }\end{array}$ & 9 & DVFIVDNGK & \\
\hline $\begin{array}{l}\mathrm{HBH}>\mathrm{HWN} \text { spot } 2 \text {, protein } 1, \\
\text { peptide } 9 \text { (c64389_g2) }\end{array}$ & 10 & HPLVPVSVVK & \\
\hline $\begin{array}{c}\mathrm{HBH}>\mathrm{HWN} \text { spot } 2 \text {, protein } 2 \\
(\text { c103934_g1) }\end{array}$ & 39 & $\begin{array}{l}\text { LEKLEKLARKAAEKMQKKKDKKGKKDKKKDK } \\
\text { KSKKDKKK }^{*}\end{array}$ & unknown $S y m$ \\
\hline $\begin{array}{c}\mathrm{HBH}>\mathrm{HWN} \text { spot } 2 \text {, protein } 3 \\
\left(\mathrm{c} 185341 \_\mathrm{g} 1\right)\end{array}$ & 39 & $\begin{array}{l}\text { DDRDRDRGHDRERSFEERRPRDDRDGRYRDDR } \\
\text { DGRDRGR* }\end{array}$ & unknown Sym \\
\hline $\begin{array}{l}\mathrm{HBH}>\mathrm{HWN} \text { spot } 2 \text {, protein } 4 \\
\quad\left(\mathrm{c} 61072 \_\mathrm{g} 1\right)\end{array}$ & 46 & $\begin{array}{l}\text { VRQVPSGLTQPCTLVPKRGHEPVWRHWNISFW } \\
\text { KEACGLEYCNCRSR }^{*}\end{array}$ & $\begin{array}{l}\text { Sym HSPB1-associated } \\
\text { protein 1-like }\end{array}$ \\
\hline $\begin{array}{l}\mathrm{HBH}>\mathrm{HWN} \text { spot } 2 \text {, protein } 5 \\
\text { peptide } 1 \text { (c59669_g2) }\end{array}$ & 19 & DEEDEEASKEDEEKEDEAK & unknown host \\
\hline $\begin{array}{l}\mathrm{HBH}>\mathrm{HWN} \text { spot } 2 \text {, protein } 5, \\
\text { peptide } 2 \text { (c59669_g2) }\end{array}$ & 19 & CQWPCMWPCCCECDPPKFK & \\
\hline $\begin{array}{l}\mathrm{HBH}>\mathrm{HWN} \text { spot } 3 \text {, protein } 1, \\
\text { peptide } 1 \text { (c31796_g1) }\end{array}$ & 35 & $\begin{array}{c}\text { ADTAASESEGAKYDEPDTETEDEADKHRRLPM } \\
\text { HGR }\end{array}$ & unknown Sym \\
\hline $\begin{array}{l}\mathrm{HBH}>\mathrm{HWN} \text { spot } 3 \text {, protein } 1, \\
\text { peptide } 2 \text { (c31796_g1) }\end{array}$ & 28 & SKVKАКАКАКАКАКАКАКРКАКАКАКАК & \\
\hline $\begin{array}{c}\mathrm{HBH}>\mathrm{HWN} \text { spot } 3 \text {, protein } 2, \\
\text { peptide } 1\left(\mathrm{c} 108872 \_\mathrm{g} 1\right)\end{array}$ & 18 & THRERQRQDEELREQKER & $\begin{array}{l}\text { host protein split } \\
\text { ends isoform X1 }\end{array}$ \\
\hline $\begin{array}{c}\mathrm{HBH}>\mathrm{HWN} \text { spot } 3 \text {, protein } 2, \\
\text { peptide } 2\left(\mathrm{c} 108872 \_\mathrm{g} 1\right)\end{array}$ & 22 & EKERKEKEQREREAREREQRER & \\
\hline $\begin{array}{c}\mathrm{HBH}>\mathrm{HWN} \text { spot } 3 \text {, protein } 3 \\
\text { peptide } 1 \text { (c62707_g1) }\end{array}$ & 16 & NGLGEEFTGSDANLKK & host beta-gamma crystallin \\
\hline $\begin{array}{c}\mathrm{HBH}>\mathrm{HWN} \text { spot } 3 \text {, protein } 3, \\
\text { peptide } 2 \text { (c62707_g1) }\end{array}$ & 9 & HGFYGGFSK & \\
\hline $\begin{array}{c}\mathrm{HBH}>\mathrm{HWN} \text { spot } 3 \text {, protein } 3, \\
\text { peptide } 3 \text { (c62707_g1) }\end{array}$ & 35 & $\begin{array}{l}\text { GAGVSSAIVLSKNENFAIFTETNYKGIE } \\
\text { QQLDAGK**}\end{array}$ & \\
\hline
\end{tabular}




\begin{tabular}{|c|c|c|c|}
\hline Name & $\begin{array}{l}\text { Length } \\
\text { (\#AA) }\end{array}$ & Sequence & Protein identity \\
\hline $\begin{array}{c}\mathrm{HBH}>\mathrm{HWN} \text { spot 3, protein } 4 \\
\text { (c37656_g1) }\end{array}$ & 18 & DRSKAALDTKAEPKDRSK & unknown $S y m$ \\
\hline $\begin{aligned} \text { HWN }>\text { HBH spot 1, protein } 1 \\
\quad\left(\mathrm{c} 146943 \_\mathrm{g} 1\right)\end{aligned}$ & 26 & KKTYTKPKKIKHKRKKVKLAVLKFYK* & $\begin{array}{l}\text { Sym ubiquitin-40S } \\
\text { ribosomal protein S27a }\end{array}$ \\
\hline $\begin{aligned} \text { HWN }>\text { HBH spot } 1, \text { protein } 2 \\
\text { (c30229_g1) }\end{aligned}$ & 31 & $\begin{array}{l}\text { KKEKAVKKKDKKKDKKDKKKKKD } \\
\text { KKGKKKKK* }^{*}\end{array}$ & unknown $S y m$ \\
\hline $\begin{array}{l}\text { HWN }>\text { HBH spot } 1 \text {, protein } 3 \text {, } \\
\text { peptide } 1 \text { (c71519_g1) }\end{array}$ & 18 & KTFRPKLTSENQMECFKK & host putative transcription factor \\
\hline $\begin{array}{l}\text { HWN }>\text { HBH spot } 1 \text {, protein } 3 \text {, } \\
\text { peptide } 2 \text { (c71519_g1) }\end{array}$ & 32 & $\begin{array}{c}\text { DNQSEFMTHMANVHPDREKGPW } \\
\text { MNKNTNLCAR }\end{array}$ & Ovo-like 1 \\
\hline $\begin{array}{l}\text { HWN }>\text { HBH spot } 1 \text {, protein } 4 \text {, } \\
\text { peptide } 1\left(\mathrm{c} 32821 \_\mathrm{g} 1\right)\end{array}$ & 33 & TRKEFQPLLEAKKLERVKKRNEELDRIERVERK & $\begin{array}{l}\text { host leucine-rich repeat and IQ } \\
\text { domain-containing }\end{array}$ \\
\hline $\begin{array}{l}\text { HWN }>\text { HBH spot } 1 \text {, protein } 4 \text {, } \\
\text { peptide } 2 \text { (c32821_g1) }\end{array}$ & 15 & KKEEEKRTREEIQRK & protein 1 \\
\hline $\begin{array}{l}\text { HWN }>\text { HBH spot } 1 \text {, protein } 5 \text {, } \\
\text { peptide } 1 \text { (c79274_g3) }\end{array}$ & 21 & CECYENYHSPETGCDRSFCAK & $\begin{array}{l}\text { host von Willebrand } \\
\text { factor D and EGF }\end{array}$ \\
\hline $\begin{array}{l}\text { HWN }>\text { HBH spot } 1 \text {, protein } 5 \text {, } \\
\text { peptide } 2 \text { (c79274_g3) }\end{array}$ & 26 & KCHCDEGWDNQIHVSGFNAHFGPCKK & domain-containing protein \\
\hline $\begin{array}{l}\text { HWN }>\text { HBH spot } 1 \text {, protein } 6 \text {, } \\
\text { peptide } 1\left(\mathrm{c} 288 \_g 1\right)\end{array}$ & 25 & AARMSRVGTKAGRVVRLLRLVRLIR & Sym adenylate cyclase \\
\hline $\begin{array}{l}\mathrm{HWN}>\mathrm{HBH} \text { spot } 1 \text {, protein } 6 \text {, } \\
\text { peptide } 2\left(\mathrm{c} 288 \_\mathrm{g} 1\right)\end{array}$ & 32 & RGQQRDPDAESDAKRNCCSRCCSATLKCIRRR & \\
\hline $\begin{array}{c}\mathrm{HWN}>\mathrm{HBH} \text { spot 2, protein } 1 \\
\text { (c63186_g1) }\end{array}$ & 29 & KTVKMIEKQLALKKLKKKSKISKKHPKKK* & unknown host \\
\hline $\begin{array}{c}\text { HWN }>\text { HBH spot 2, protein 2, } \\
\text { peptide } 1 \text { (c69424_g1) }\end{array}$ & 20 & DIDYGCMEGSCAMEYCQHTK & unknown host \\
\hline $\begin{array}{c}\text { HWN }>\text { HBH spot 2, protein 2, } \\
\text { peptide } 2 \text { (c69424_g1) }\end{array}$ & 26 & CGQKEDCRKAAESWGNCKAFSCFANR & \\
\hline $\begin{array}{c}\text { HWN }>\text { HBH spot 2, protein } 3 \text {, } \\
\text { peptide } 1 \text { (c73482_g1) }\end{array}$ & 20 & CRNWSQCKKDECCIRYSVNK & unknown host \\
\hline $\begin{array}{l}\mathrm{HWN}>\mathrm{HBH} \text { spot } 2 \text {, protein } 3 \text {, } \\
\text { peptide } 2\left(\mathrm{c} 73482 \_\mathrm{g} 1\right)\end{array}$ & 15 & TTKWGQKKHRCERLR & \\
\hline $\begin{array}{c}\mathrm{HWN}>\mathrm{HBH} \text { spot 2, protein } 4 \\
\text { (c79716_g1) }\end{array}$ & 41 & $\begin{array}{l}\text { RLADERKMLEEEEMQRQIDMERRRKEEEERRKR } \\
\text { DTEERRKR }{ }^{*}\end{array}$ & host debrin-like \\
\hline $\begin{array}{c}\text { HWN }>\text { HBH spot 3, protein } 1 \\
\quad(\text { c117310_g1) }\end{array}$ & 36 & $\begin{array}{l}\text { EERKRQRHEAIWKEWKKLLRSLVVYVKFRLPLR } \\
\text { KTR* }^{*}\end{array}$ & $\begin{array}{c}\text { Sym } \\
\text { alpha-1,2-mannosyltransferase } \\
\text { ALG9 }\end{array}$ \\
\hline
\end{tabular}




\section{Continued}

\begin{tabular}{|c|c|c|c|}
\hline Name & $\begin{array}{l}\text { Length } \\
\text { (\#AA) }\end{array}$ & Sequence & Protein identity \\
\hline $\begin{array}{l}\text { HWN }>\text { HBH spot } 3 \text {, protein } 2, \\
\text { peptide } 1 \text { (c147855_g1) }\end{array}$ & 21 & EHPLILAWQALFNGYWNTKSR & Sym hippocalcin-like protein 1 \\
\hline $\begin{array}{l}\text { HWN }>\text { HBH spot } 3 \text {, protein } 2 \text {, } \\
\text { peptide } 2 \text { (c147855_g1) }\end{array}$ & 15 & WRGKTDNSWLEYVKK & \\
\hline $\begin{array}{l}\text { HWN }>\text { HBH spot 3, protein 3, } \\
\text { peptide } 1 \text { (c192890_g1) }\end{array}$ & 22 & MSLLQHWRCSLRSHVRFLRTSR & Sym bestrophin/ \\
\hline $\begin{array}{l}\text { HWN }>\text { HBH spot 3, protein } 3 \text {, } \\
\text { peptide } 2 \text { (c192890_g1) }\end{array}$ & 38 & $\begin{array}{c}\text { INCCFDAIFTTVHRGQMLGVYSSEL } \\
\text { ASGMYELASNMFR }\end{array}$ & dioxygenase AlkB-like \\
\hline $\begin{array}{l}\text { HWN }>\text { HBH spot 3, protein } 4, \\
\text { peptide } 1 \text { (c28876_g1) }\end{array}$ & 16 & DRSRSPHRSPRRSPRR & unknown $S y m$ \\
\hline $\begin{array}{l}\text { HWN }>\text { HBH spot 3, protein } 4, \\
\text { peptide } 2 \text { (c28876_g1) }\end{array}$ & 22 & DDRWKDRNDRNDRSDRSDRNDR & \\
\hline $\begin{array}{l}\text { HWN }>\text { HBH spot 3, protein } 5 \text {, } \\
\text { peptide } 1 \text { (c65959_g1) }\end{array}$ & 17 & TLDEIQKLDAEDESLVR ${ }^{\star *}$ & $\begin{array}{l}\text { host Rho GDP-dissociation } \\
\text { inhibitor } 1\end{array}$ \\
\hline $\begin{array}{l}\text { HWN }>\text { HBH spot 3, protein } 5 \text {, } \\
\text { peptide } 2 \text { (c65959_g1) }\end{array}$ & 15 & AGPQEYLTPLDEAPK & \\
\hline $\begin{array}{l}\text { HWN }>\text { HBH spot 3, protein } 6 \\
\text { peptide } 1 \text { (c69652_g1) }\end{array}$ & 38 & $\begin{array}{c}\text { KENKSKPNHAAKSKVAKKKKLKVKGTPLTSLSK } \\
\text { TVTYK }\end{array}$ & unknown host \\
\hline $\begin{array}{l}\text { HWN }>\text { HBH spot 3, protein } 6 \\
\text { peptide } 2 \text { (c69652_g1) }\end{array}$ & 25 & HCHASCLTNCLPSCGSGCCSADEER & \\
\hline $\begin{array}{l}\text { HWN }>\text { HBH spot } 3 \text {, protein } 7 \text {, } \\
\text { peptide } 1 \text { (c75440_g1) }\end{array}$ & 28 & DSTETGEPGNYGVGFPTFLGKVEDPEAR** & (1) \\
\hline $\begin{array}{l}\text { HWN }>\text { HBH spot } 3 \text {, protein } 7 \text {, } \\
\text { peptide } 2 \text { (c75440_g1) }\end{array}$ & 8 & LAAELANGR & a-c binding protein \\
\hline $\begin{array}{l}\text { HWN }>\text { HBH spot 3, protein 7, } \\
\text { peptide } 3 \text { (c75440_g1) }\end{array}$ & 26 & ELGVQDPIGFWDPLGLSADKDEATFK & \\
\hline $\begin{array}{l}\text { HWN }>\text { HBH spot } 3 \text {, protein } 8, \\
\text { peptide } 1 \text { (c76783_g1) }\end{array}$ & 31 & TPVSESSDERSNSDSSDHNLERESSPVKRRK & host corine/aroinine \\
\hline $\begin{array}{c}\text { HWN }>\text { HBH spot } 3 \text {, protein } 8, \\
\text { peptide } 2 \text { (c76783_g1) }\end{array}$ & 32 & QRHLDKSDARRERKMRDDHENRHDEERLRRER & repetitive matrix protein 2 \\
\hline 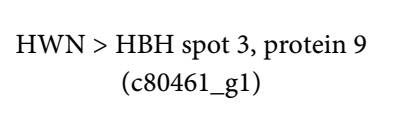 & 25 & KTVKVLRVLRVLRPLKAINKAKKLK* & $\begin{array}{l}\text { host voltage-dependent R-type } \\
\text { calcium channel subunit } \\
\text { alpha-1E-like isoform X2 }\end{array}$ \\
\hline $\begin{array}{c}\mathrm{HWN}>\mathrm{HBH} \text { spot } 3 \text {, protein } 10, \\
\text { peptide } 1 \text { (c86107_g1) }\end{array}$ & 20 & TRKLKSRIIKRIRRLRVLRR & unknown host \\
\hline $\begin{array}{l}\mathrm{HWN}>\mathrm{HBH} \text { spot } 3 \text {, protein } 10, \\
\text { peptide } 2(\mathrm{c} 86107 \text { g1 })\end{array}$ & 21 & KAKQVLVKRVRKMKRKIKRRK & \\
\hline
\end{tabular}




\begin{tabular}{|c|c|c|c|}
\hline Name & $\begin{array}{l}\text { Length } \\
\text { (\#AA) }\end{array}$ & Sequence & Protein identity \\
\hline $\begin{aligned} \text { HWN }> & \text { HBH spot } 4 \text {, protein } 1 \\
& (\text { c62634_g1) }\end{aligned}$ & 28 & SVKKVTKKAKKAKKAKKVIRKRKAPAKR* & host protamine \\
\hline $\begin{array}{l}\text { HWN }>\text { HBH spot } 4 \text {, protein } 2 \text {, } \\
\quad \text { peptide } 1 \text { (c80550_g3) }\end{array}$ & 14 & FTCANGHCINFDWK & host prolow-density lipoprotein \\
\hline $\begin{array}{l}\text { HWN }>\text { HBH spot } 4 \text {, protein } 2 \text {, } \\
\text { peptide } 2 \text { (c80550_g3) }\end{array}$ & 20 & RWQCDGEDDCGDGSDEGLCK & receptor-related protein 1 \\
\hline $\begin{array}{l}\text { HWN }>\text { HBH spot } 4 \text {, protein } 2 \text {, } \\
\text { peptide } 3 \text { (c80550_g3) }\end{array}$ & 29 & CVMMSYVCDGYNDCGDASDEHPKEGCLLR & \\
\hline $\begin{array}{l}\text { HWN }>\text { HBH spot } 5 \text {, protein } 1 \text {, } \\
\quad \text { peptide } 1(\mathrm{c} 13654 \text { g1 })\end{array}$ & 22 & EYMEQWDQATIAFRTGYEVAKR & $\begin{array}{l}\text { Sym ankyrin repeat } \\
\text { domain-containing }\end{array}$ \\
\hline $\begin{array}{l}\text { HWN }>\text { HBH spot } 5 \text {, protein } 1, \\
\quad \text { peptide } 2 \text { (c13654_g1) }\end{array}$ & 16 & VILIQAAARGFLIRRR & protein 50 \\
\hline $\begin{aligned} \text { HWN }> & \text { HBH spot 5, protein } 2 \\
& (\text { c167493_g1) }\end{aligned}$ & 60 & $\begin{array}{l}\text { LTVQVVVRTQEGSYIGETRYTYNSNLLSQFEQCV } \\
\text { KAMDDEDMELDCTGSP* }\end{array}$ & unknown host \\
\hline $\begin{aligned} \text { HWN }> & \text { HBH spot 5, protein } 3 \\
& (\text { c168524_g1) }\end{aligned}$ & 27 & TLLLRKRKSLTLSLESLGKRLKVLELR* & host short-chain collagen $\mathrm{C} 4$ \\
\hline $\begin{aligned} \text { HWN }> & \text { HBH spot } 5 \text {, protein } 4 \\
& (\text { c170150_g1 })\end{aligned}$ & 34 & $\begin{array}{l}\text { KSTKVMHNFEDDDGNNEEED } \\
\text { KENDSGFGRYEEMR }^{\star}\end{array}$ & unknown host \\
\hline $\begin{array}{l}\text { HWN }>\text { HBH spot } 5 \text {, protein } 5 \text {, } \\
\text { peptide } 1 \text { (c41865_g1) }\end{array}$ & 30 & NLRFPHLLRFPDLPHLLKRKLRQQRKRPLR & unknown \\
\hline $\begin{array}{l}\text { HWN }>\text { HBH spot } 5 \text {, protein } 5 \text {, } \\
\text { peptide } 2 \text { (c41865_g1) }\end{array}$ & 32 & HRQLRVRQTQQLRLQGLLPLLSQLRRRNQRHR & \\
\hline $\begin{aligned} \text { HWN }> & \text { HBH spot 5, protein } 6 \\
& (\text { c45226_g1) }\end{aligned}$ & 31 & DDDGDKWLDNESNDFSSSEGEVDDNEKDDWK* & unknown \\
\hline $\begin{aligned} \text { HWN }> & \text { HBH spot 5, protein } 7 \\
& (\text { c46638_g1) }\end{aligned}$ & 29 & KGSKKKKGSKKKKGSKKKKKKGKKKGKKK & unknown \\
\hline $\begin{array}{l}\text { HWN }>\text { HBH spot } 5 \text {, protein } 8 \\
\text { peptide } 1 \text { (c51777_g1) }\end{array}$ & 18 & TQMIPNRTYCIWYQVEPR & unknown Sym \\
\hline $\begin{array}{l}\text { HWN }>\text { HBH spot } 5 \text {, protein } 8 \\
\quad \text { peptide } 2 \text { (c51777_g1) }\end{array}$ & 38 & $\begin{array}{l}\text { DQPLETKPLETVRLAQLLSLGFT } \\
\text { VISEEANSLDSELYK }\end{array}$ & \\
\hline $\begin{aligned} \text { HWN }> & \text { HBH spot 5, protein } 9 \\
& \text { (c52097_g1) }\end{aligned}$ & 30 & LRKKIREATLAGIREKKKHVDRMHRKRRFR* & $\begin{array}{l}\text { Sym DEAD-box ATP-dependent } \\
\text { RNA helicase } 35\end{array}$ \\
\hline 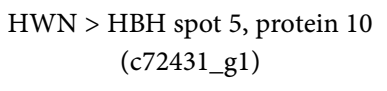 & 30 & KРКKEKKKKKGKKEKKKKDKKDKKEKKKKK & host Schlafen family member 5 \\
\hline $\begin{array}{l}\text { HWN }>\text { HBH spot } 5 \text {, protein } 11, \\
\text { peptide } 1 \text { (c77868_g2) }\end{array}$ & 36 & $\begin{array}{c}\text { KRLEERRRERILERKVQRRIEREE } \\
\text { KERKEKEEREKR }\end{array}$ & $\begin{array}{l}\text { host eukaryotic translation } \\
\text { initiation factor } 3\end{array}$ \\
\hline $\begin{array}{l}\text { HWN }>\text { HBH spot } 5 \text {, protein } 11, \\
\text { peptide } 2(\mathrm{c} 77868 \text { g2 })\end{array}$ & 20 & WRDDRGRDDRGRDDRWRVDR & subunit A-like \\
\hline
\end{tabular}


A. B. Mayfield et al.

\section{Continued}

\begin{tabular}{|c|c|c|c|}
\hline Name & $\begin{array}{l}\text { Length } \\
\text { (\#AA) }\end{array}$ & Sequence & Protein identity \\
\hline $\begin{array}{l}\text { HWN }>\text { HBH spot 5, protein } 12 \\
\quad(\text { c97047_g1) }\end{array}$ & 24 & KKDKKKSDKKKKKDKKKKKDKKKK** & unknown $S y m$ \\
\hline $\begin{aligned} \text { HWN }> & \text { HBH spot 6, protein } 1 \\
& \text { (c29807_g1) }\end{aligned}$ & 18 & YLRILRLLRLARLLRVIK & $\begin{array}{l}\text { Sym serine/threonine } \\
\text { protein kinase pelle }\end{array}$ \\
\hline $\begin{array}{c}\text { HWN }>\text { HBH spot 6, protein } 2 \\
\quad \text { (c37817_g1) }\end{array}$ & 21 & VTEVVLLEREQRVRARLLRPK & unknown $S y m$ \\
\hline $\begin{aligned} \text { HWN }> & \text { HBH spot 6, protein } 3 \\
& \text { (c48738_g1) }\end{aligned}$ & 20 & EKKHKDKEHKKDKKEKKEKK & Sym DNA topoisomerase I \\
\hline $\begin{array}{c}\text { HWN }>\text { HBH spot } 6 \text {, protein } 4 \\
\text { (c52240_g1) }\end{array}$ & 28 & RFKGILKIRRKKMKKHKYRKRRKRDLFK* & unknown host \\
\hline mean length of se & nced pept & xcluding overlapping samples) & $22 \pm 9$ (std. dev.) AA \\
\hline \multicolumn{3}{|c|}{ total number of proteins } & 53 \\
\hline \multicolumn{3}{|c|}{ total number of contiguous peptide sequences } & 95 \\
\hline \multicolumn{3}{|c|}{ total number of peptides sequenced } & 129 \\
\hline
\end{tabular}

${ }^{a}$ compartment of origin could not be verified. 